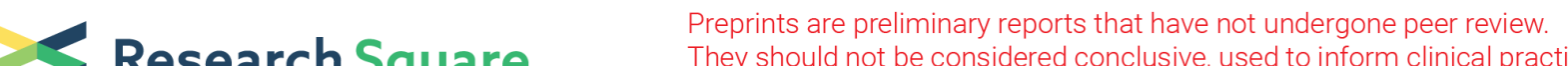 Research Square $\quad \begin{aligned} & \text { They should not be considered conclusive, used to inform clinical practice, } \\ & \text { or referenced by the media as validated information. }\end{aligned}$
}

\section{Flood Hazards and Livelihood Vulnerability of Flood- Prone Farm Dependent Bait Households in Punjab, Pakistan}

Dilshad Ahmad ( $\sim$ dilshad@ciitvehari.edu.pk)

COMSATS University Islamabad, Vehari Campus Pakistan https://orcid.org/0000-0002-3991-805X

Muhammad Afzal

Preston University Islamabad Pakistan

\section{Research Article}

Keywords: Flood disasters, Exposure, Bait communities, Livelihood vulnerability index, Punjab

Posted Date: June 23rd, 2021

DOl: https://doi.org/10.21203/rs.3.rs-327153/v1

License: (c) (1) This work is licensed under a Creative Commons Attribution 4.0 International License.

Read Full License

Version of Record: A version of this preprint was published at Environmental Science and Pollution Research on September 18th, 2021. See the published version at https://doi.org/10.1007/s11356-02116443-4. 
Dilshad Ahmad

Department of Management Sciences

COMSATS University Islamabad, Vehari Campus Pakistan

Corresponding author: dilshad@ ciitvehari.edu.pk

https://orcid.org/0000-0002-3991-805X

\author{
Muhammad Afzal \\ Department of Economics \\ Preston University Islamabad, Pakistan \\ profafzal@gmail.com
}




\section{Abstract}

33 Pakistan is one of the most climate change and natural disasters affected country of the world where livelihood and lives of inhabitants

34 are often affected due to these disasters. In the scenario of various disasters and risks, flood disasters are the most recurrent hazards

35 that causes Bait households livelihood more vulnerable. Hence this research work has focused to investigate livelihood vulnerability

36 of flood-prone Bait households in southern Punjab of Pakistan. This study used multistage sampling technique for collection the cross

37 sectional data of 398 flood disasters vulnerable Bait household's respondents from three high risks flood-prone districts Muzaffargarh,

38 Rajanpur and Rahim Yar Khan. Face to face interview procedure and well developed pre-tested questionnaire was used for data

39 collection in this research work. This study applied vulnerability framework of LVI-IPCC and LVI in the direction of comparing the

40 level of vulnerabilities in preferred three Bait district households. Empirical estimates of LVI major components and framework of

41 IPCC vulnerability have indicated Bait households of Muzaffargarh more vulnerable owing to higher exposure and sensitivity and 
lower adaptive capacity rather than other districts. In contrast to other districts Muzaffargarh households have investigated more vulnerable to flood disasters more particularly in LVI sub-components such as health (0.460), water (0.360) and food (0.515) access. These research findings will helpful to policymakers to work out and put into practice effectual programs and strategies such as constructing more water reserves, developing overhead infrastructure, easy access of institutional loans and generating off-farm income sources. These local based feasible measures will helpful for native inhabitants to reducing frequency of floods in the direction of lessen vulnerability and increase resilience via recovering generally the livelihood of vulnerable Bait households in Punjab Pakistan and particularly the district Muzaffargarh.

Keywords; Flood disasters, Exposure, Bait communities, Livelihood vulnerability index, Punjab

\section{Introduction}

Floods, earthquakes, landslides, cyclones and droughts are some significant natural hazards owing to greater than before incidence of excessive climate change (Toe et al., 2018; Eckstein et al., 2019; Ahmad et al., 2019; Elahi et al., 2021). In current global scenario, floods are considered the most consecutive and more destructive rather than other hazards (Toe et al., 2018; Ahmad et al., 2019; Al Baky et al., 2020; Hoq et al., 2021) the reason of considerable involvement to social risk, economic losses and human fatalities as mainly exposed by human (Abbas et al., 2017; Huong et al., 2019; Ahmad and Afzal, 2021). These natural disasters affected more than 96 million peoples throughout the world in 2017 in which majority population 60\% was affected from flood hazards (World Bank, 2013; Emergency Event Database (EEDAT), 2017; Eckstein et al., 2019). In the current couple of decades, rising recurrence and severity of floods have estimated more particularly in South Asian and South East Asian countries (Krausmann and Mushtaq, 2008; Hirabayashi et al., 2013; Toe et al., 2018; Hussin et al., 2019) where some Asian countries India, China, Bangladesh and 
Pakistan are indicated as supermarkets of flood disasters (James, 2008; Abid et al., 2016; Ahmad et al., 2019). Scare resources, inadequate infrastructure and limited flood adaptive mitigation measures are significant factors of increasing flood vulnerability (Daniell et al., 2016;Abbas et al., 2017) mostly for rural community in developing countries (Zhang et al., 2011; Abid et al., 2016). More particularly in developing countries, anthropogenic factors such as human encroachment in rivers coupled with environmental and climatic change have played major role to increasing flood hazards (Gaurav et al., 2011; Toe et al., 2018).

In the global scenario, Pakistan indicated as world $5^{\text {th }}$ most natural hazards affected country (Eckstein et al., 2019) due to specifically located in hazards prone region and facing frequent floods (Abbas et al., 2017; Ahmad and Afzal, 2021). Glacier melting, erratic rains and expanding cycle of monsoon rainfalls are significant factors correlated to consecutive floods in interlined rivers concerning upstream or downstream rivers (Teo et al., 2018; Ahmad et al., 2020). In scenario of natural hazards as more specifically the flood hazards, Pakistan faced the worst flood disaster of history in 2010, which caused cumulative economic cost of 10 billion US dollars, destroy cropped area of two million hectares and twenty-four million peoples were adversely affected (Rafique and Blaschke, 2012; United Nations, 2011; Khan, 2011; Abid et al., 2016).

In the last couple of decades, inhabitants of Punjab province of Pakistan pragmatic climate based drastic changes including the more significant and affecting factors such as evident precipitation, grain production changes, weather pattern alteration, droughts, floods and weather pattern shifting (BOS Punjab, 2017). In Punjab, climate vulnerability mostly contributed by various sectors such as urbanization, industrialization, agriculture, transportation, waste and energy which directly rises the Green House Gases emission (Hussain et al., 2019). An increasing scenario of atmospheric pollution in Punjab is the reason of incompetency and inconsistencies about the understanding the geography, climate and production factors (Qayyum et al., 2016; Hussain et al., 2019). In the last, three decades, mean temperature of climate warning trend observed in the range of $0.78{ }^{\circ} \mathrm{C}$ to $1.5^{\circ} \mathrm{C}$ which is predictable to increase $2{ }^{\circ} \mathrm{C}$ to $4{ }^{\circ} \mathrm{C}$ (Rasul et al., 2012; IPCC, 2014; Abbas et al., 2017; Bokhari et al., 2018) and such dramatic rise in temperature severely affect agricultural production of Punjab province (Abbas et al., 2017; Amin et al., 2018; Tariq et al., 2018). Events of extreme temperature, 
droughts and floods are some significant climate related risks which negatively affects farming system and livelihood through water shortage and crop yield losses (Gorst et al., 2018; Ahmad and Afzal, 2020). More specifically in current few years climate change caused severe losses of staple crops such as wheat production declined 2.26\% in 2017, 4.4\% in 2018 and in early quarter of 2019 unexpected weather conditions as hailstorms, windstorms and heavy rains caused significant losses to standing wheat crop. Punjab province area consists of fertile lands, categorized as arid land in southern region whereas semi arid in central region and precipitation occurs in monsoon season from month of July to August (Mehmood et al., 2016; Abbas et al., 2017).

Punjab is officially recognized the land of five rivers Chenab, Jehlum, Ravi, Indus and Sutlej (Pakistan Bureau of Statistics (PBS), 2019). Chenab and Indus are major rivers of Pakistan (Ahmad et al., 2021) more prominently causes severe floods destructions specifically in summer season (UNDP, 2019). In flowing process, these rivers naturally dispersed in different temporary channels when passing through various areas as temporary islands are usually generated within the area of river. In the region of southern Punjab, these temporary islands within the rivers in local language Saraiki are formally known as Bait ${ }^{l}$, areas. Local community particularly inhabited in the neighbouring of these rivers usually settle and performs their farming practices in these islands and mostly cultivate such Bait areas. In flooding season, these Bait areas are in a straight line under fire by rivers. In floods and rainy season these communities have to undergo severe losses of livestock, crops, human fatalities, damages of infrastructure and destruction of houses. Southern Punjab region in Punjab province is higher vulnerable of flooding due to side by side flowing of Chenab and Indus rivers (PDMA, 2017). Livelihood status of Bait farming community adversely affected due to consecutive occurrence of floods rather than farming community from rest of the region, province or country. Southern Punjab Bait household inhabitants of Pakistan are higher vulnerable to flood hazards due to using inadequate measure of mitigation to overcoming these natural disasters risks. Inadequate communication and awareness sources, limited role of disaster institutions, and lack of resources allocation to hazards mitigation measures major factors to increasing vulnerabilities of Bait inhabitants (Singh and Sagar, 2012; Ahmad and Afzal, 2021).

\footnotetext{
${ }^{1}$ Temporary islands are usually generated within the area of river in local language Saraiki are formally known as Bait
} 
In literature, some studies of developed and developing countries specifically considered the aspect of flood risks adaptation (Birkholz et al., 2014; Lopez-Marrero and Yarnal, 2010), constraints and choice of mitigation of floods (Paul and Routray, 2010; Wisner et al., 2004), flood risk management (Wilby and Keenan, 2012; Osberghaus, 2015) and livelihood vulnerability to flood hazards (Hoq et al., 2021). In Pakistan for the most part of flood hazards literature determined the aspect of flood hazards management and assessment (Hashmi et al., 2012; Bahadar et al., 2015; Tariq and Van De Giesen, 2012), flood hazards perception and adaptation strategies (Ahmad and Afzal, 2020; Ahmad et al., 2020), floods causes, consequence and protection measures (Yaqub et al., 2015; Khan, 2011), riverbank erosion and inundation of hazards zone (Khan et al., 2017; Ali and De Boer, 2010), riverbank erosion and protection work (Ashraf and Shakir, 2018; Khan and Ali, 2003), some studies focused the aspect of adaptation level and local mitigation measures about affects of post floods (Abbas et al., 2017; Abid et al., 2016). In Pakistan, limited research specifically firmed the aspect of flood hazards affect of food security and poverty (Ali and Rahut, 2020; Ashraf and Shakir, 2018), flood hazards resilience (Ahmad et al., 2019), flood persuaded vulnerability and risks of health (Shah et al., 2020), and gender based aspect of flood hazards adaptation strategies (Ahmad et al., 2021).

In the above mentioned available literature, the aspect of flood hazards, livelihood vulnerability of flood-prone farm dependent household's poorly addressed in global scenario whereas according the best knowledge of author this aspect not appropriately addressed in developing countries particularly to Pakistan where agriculture sector is badly affected due to severe natural disasters like floods. To address such research gap in specific scenario of Pakistan this study focused to highlight the flood hazards, livelihood vulnerability of flood-prone farm dependent households Bait communities in Punjab, Pakistan. Objective of this research work is to examine the flood hazards and livelihood vulnerability of flood-prone farm dependent households Bait communities in Punjab, Pakistan. There is some significance of this study in scenario of Pakistan, firstly no research work in this area tried to explore the aspect of Bait community flood hazards livelihood vulnerability in literature as this study tried to focus this aspect. Secondly, no study in Pakistan has used Livelihood Vulnerability Index (LVI) all indicators for vulnerability estimation as this research work carried out to explore the vulnerability of Bait community household through all indicator of LVI also through LVI and IPCC components. This 
research is classified in to five sections, introduction elaborated in first section, data and methodology explained in second section and third section highlighted the empirical results of the study. In section four discussions is indicated whereas last section of the study illustrated conclusion and suggestion.

\section{Data and methodology}

\subsection{Rationalization of study area selection}

In four provinces of Pakistan, Punjab was selected for this study owing to few significant reasons. Firstly, Punjab shares 52.95\% population, 26\% area and supply 53\% agricultural GDP of the country (PBS, 2017). Secondly, Punjab among four provinces is higher vulnerable of floods hazards due to consecutive flowing of five rivers throughout the fertile lands of province (PDMA, Punjab 2017). Thirdly, southern Punjab region more particularly selected for study the reason of located both sides of Pakistan's largest river Indus and consecutively facing flood disasters (BOS, 2017; NDMA, 2018). Fourthly, in region of southern Punjab Bait communities inhabited in the temporary island due to riverine distributor channels of Indus River and engaged farming practices, more vulnerable of flood hazards specifically focused for this study. Lastly, based on mostly flood risk seven districts Bait communities of Punjab, higher flood risk disasters vulnerable three district Muzaffargarh, Rajanpur and Rahim Yar Khan Bait communities were (PDMA, Punjab 2014) more preferably selected for the study.

\section{[Figure 1]}

\subsection{Study area geographical feathers}

Muzaffargarh district consists four tehsils (sub-district in district area) Kot addu, Jatoi, Alipur, Muzaffargarh and 93 union councils (Pakistan fifth administrative unit and local government second tire) (Government of Pakistan (GOP), 2020) with area of 8249 km² and population of 4,322, 009 (PBS, 2017). Muzaffargarh district consider higher vulnerable to consecutive flood disaster owing to located in critical geographical scenario surrounded by two major rivers as Indus flows western side while Chenab flows eastern side 
of district (Bureau of Statistics (BOS) Punjab, 2019). Mild winter and hot summer, average rainfall of $127 \mathrm{~mm}$ with highest $54^{\circ} \mathrm{C}$ $\left(129^{\circ} \mathrm{F}\right)$ and lowest $1^{\circ} \mathrm{C}\left(30^{\circ} \mathrm{F}\right)$ temperature are some significant feathers of this area (Pakistan Metrological Department (PMD), 2019). In the couple of decades, this district faced erratic rainfall and frequent floods those caused foremost losses of infrastructure, crops, livestock and human fatalities (PDMA Punjab, 2014) and due to lowest social progress index and cultural, social and economic dimensions indicated as lower socioeconomic status district (BOS Punjab, 2019).

\section{[Figure 2]}

Rahim Yar Khan district administratively divided in to four tehsils (sub-district in district area) Khanpur, Liaqatpur, Sadiqabad and Rahim Yar Khan (GOP, 2020) by area of 11,880 $\mathrm{km}^{2}$ and population of 4,814, 006 (PBS, 2017) higher vulnerable due to extreme flood disasters as located on eastern bank of river Indus (PDMA Punjab, 2014). In scenario of long and extreme summer Rahim Yar Khan regarded as hot region with average temperature $26.2^{\circ} \mathrm{C}$ in this area (PMD, 2019). Majority population (65\%) of district affiliated with agriculture (BOS Punjab, 2019) whereas during the current couple of decades because of climate change having sever issues of excessive flood hazards and confronted with losses of infrastructure, livestock, crops and human fatalities (PDMA, 2014). District Rajanpur covers the area of $12,318 \mathrm{~km}^{2}$ and consists population of 1,995,958 and administratively divided in to three tehsils (sub-district in district area) Jampur, Rojhan and Rajanpur (BOS Punjab, 2019). Long and extreme summer in district Rajanpur indicated region hot weather which frequently stuck strongly excessive flooding with major destruction of infrastructure, crops and human fatalities due to situated on the western bank of Indus River (PBS, 2017).

These three districts share some diverse and common demographic and socioeconomic feathers which play significant role on livelihood vulnerability of flood-prone farm dependent Bait households in Punjab, Pakistan. In these three districts some minor variation in family average size was indicated from 9 to 11 members (PBS, 2017) whereas some significant variation regarding land holding average size among these study districts indicated as lower land holding average size in Muzaffargarh (4.4 acres) as compared to Rahim Yar Khan (6.4 acres) and Rajanpur (5.4 acres) (PBS, 2010; BOS Punjab, 2017) Some variation in agricultural income 
significance in total income was estimated among three districts as higher importance of agricultural income was in Rahim Yar Khan (85\%) rather than Rajanpur (74\%) and Muzaffargarh (69\%) (Nazli et al,. 2012: Abid et el., 2016; BOS, Punjab 2018).

2.3 Sampling technique and data collection

Multistage sampling technique was used in this study for data collection, firstly based on higher vulnerability of floods destruction Punjab among four provinces preferred for this study (PDMA, 2014). Secondly, Bait communities of southern Punjab region because of higher vulnerability and consecutive flooding specifically focused for this study. Thirdly, out of seven riverine Bait communities' districts of province, three higher risk flood hazards vulnerable districts Rajanpur, Rahim Yar Khan and Muzaffargarh (PDMA Punjab, 2017; National Disaster Management Authority (NDMA), 2018) Bait communities were particularly selected for the study. Fourthly, two tehsils from each district and two union councils each tehsil were purposively chosen on the basis of flood vulnerability according to list provided from District Disaster Management Authority (DDMA), local land record officer (patwari) and agriculture officer. Lastly, two Bait community villages from each union council were selected based on higher flood destruction and vulnerability and sixteen farmer's respondents from each village were randomly selected and were interviewed.

In data collection households indicated basic unit and head of household (female/male) considered major respondents of this study area. For attaining sample size minimum level, this study employed Cochran (1977) sampling method as elaborated in equation 1. Household heads were specifically targeted for data collection of 398 respondents and population of 5\% indicated sufficient (Kotrlik and Higgins, 2001). In equation (1) sample size indicated as SS, confidence level elaborated as Z ( \pm 1.96 at $95 \%$ ) for picking points percentage choices as $p$, as decimal explained ( 0.5 employed required sample size $)$ and value of precision was indicated as $\mathrm{e}(0.07= \pm$ 7).

$$
\text { Sample Size }=\frac{Z^{2}(p)(1-p)}{e^{2}}
$$


Direct respondent's interaction and well developed questionnaire was used for data collection from February to May 2019. In finding adequacy and accuracy of information moreover avoiding ambiguity, questionnaire was used for pilot study and pre-tested through 20 respondents prior to proper survey. Five trained enumerators and author himself corrected as well as clarified all relevant issues regarding questionnaire prior starting survey in the study area. In data collection, all respondents were clearly informed about the purpose and use of data and those respondents hesitated to sharing their information was replaced to others.

\subsection{Analytical technique}

\subsubsection{Vulnerability understanding}

In research scenario, IPCC ${ }^{2}$ definition standard structure is measured more influential methodical tool for assessment of vulnerability (IPCC, 2001). Numerous scholars in their research studies (Shah et al., 2013; Can et al., 2013; Panthi et al., 2016; Tewari and Bhowmick, 2014; Tjoe, 2016) particularly used the framework of 'indicator based assessment of vulnerability' in different perspectives developed by Hahn et al., (2009). In all major and sub-components based composite index of LVI ${ }^{3}$ was developed by Hahn et al., (2009) whereas the vulnerability index of IPCC (LVI-IPCC) altogether major components in the three causative factors adaptive capacity, sensitivity and exposure (IPCC, 2001; Hoq et al., 2021). LVI-IPCC and LVI indicators are useful for local policy makers and development organizations to recognize social, demographic and other associated factors so as to put in vulnerability of climate change at regional or community levels. Some studies indicated the less significance the scenario of how extreme events in future alter human systems of adaptive capacity and sensitivity whereas more properly focused the factors of extreme events that increases vulnerability to climate events and extreme weather (Adger, 2006; IPCC, 2014). In accessing the vulnerability this study

\footnotetext{
${ }^{2}$ Intergovernmental Panel on Climate Change

${ }^{3}$ Livelihood vulnerability index
} 
used two analysis sets firstly employing the method of balance weight average for LVI calculation, secondly using framework of IPCC (LVI-IPCC) accessing LVI calculation.

\subsubsection{Method of balance weight average for LVI calculation}

205 In calculating vulnerability level in Bait areas of Punjab this research work applied the methodology of Shah et al., (2013), Hahn et al., 206 (2009) and Hoq et al., (2021). In adopting according to the scenario of the study area some method modifications were made (Huong et al., 2019; Hoq et al., 2021). In analysis procedure, along with to seven components of LVI developed indices (Hahn et al., 2009) two more important components production and housing means (Huong et al., 2019; Sarker et al., 2019) were integrated. In the approach of Hahn et al., (2009) climate variability and natural disasters considered single major components whereas this research work considered it as two major components one by one in consistency with Sarker et al., (2019). In this study for computing in LVI, fifty-one sub-components and nine major components as indicators for livelihood were employed as indicated in table 1. Each major component contribution is diverse sub-component indicators in this approach and each major or sub component contributing equally in overall LVI (Sullivan et al., 2002; Hoq et al., 2021). Livelihood strategies (LS), socio-demographic profile (SD), water (W), foods $(\mathrm{F})$, health $(\mathrm{H})$, social network (SN), natural disasters (ND), production and housing means (PHM), climate variability (CV) indicated major components of this study. In calculate index of life expectancy that is difference ratio in actual and pre-selected minimum life expectancy and predetermined range of minimum and maximum life expectancy Human Development Index (HDI) formally expressed in equation 2 as given below

$$
\text { Index }_{s c d}=\frac{s c_{d}-s c_{\min }}{s c_{\max }-s c_{\min }}
$$
highlighted as $\mathrm{sc}_{\mathrm{d}}$, as each sub-component maximum value $\mathrm{sc}_{\max }$ and minimum vale $\mathrm{sc}_{\mathrm{min}}$ as elaborated in equation 2 . In particular, 
measuring variable frequencies like household percentage, coverage enquiry about community based water resources conflicts as given maximum value 100 and minimum 0 . Following the logic minimum and maximum values were transformed and these subcomponents were standardized in equation 2. Subsequently to each sub-component standardization calculation of every major component was made through n number of sub-component averaging by employing equation 3 .

$$
M C_{d}=\frac{\sum_{i=1}^{n} I_{n d e x_{s c d i}}}{n}
$$

227 In nine major components, one indicated as $\mathrm{MC}_{\mathrm{d}}$ and $\mathrm{d}$ as district, sub-component index as Index $\mathrm{xcdi}_{\text {, }} \mathrm{n}$ and $\mathrm{i}$ indicate sub-component 228 numbers in every major component. In equation 4, each district all major component values were calculated as LVI district level taken 229 by averaging all major components in every district.

$$
L V I_{d}=\frac{\sum_{i=1}^{n} w_{M C d i} M C_{d i}}{\sum_{i=1}^{n} w_{M C d i}}
$$

231 The notion of $\mathrm{LVI}_{\mathrm{d}}$, was indicated as LVI for the d district, and equivalent to nine major components average weighted. WMCdi 232 explained as each major component weight as calculated through sub-components numbers and incorporated to make sure that 233 contribution of all sub-components equivalently on the whole LVI (Sullivan et al., 2002) as equation 4 expressed and indicated in equation 5, such in which LVI scaled most vulnerable as 0.5 and least vulnerable as 0.

$$
L V I_{d}=\frac{W_{S D} S D_{d}+W_{L S} L S_{d}+W_{S N} S N_{d}+W_{F} F_{d}+W_{H} H_{d}+W_{W} W_{d}+W_{H P M} H P M_{d}+W_{N D} N D_{d}+W_{C V} C V_{d}}{W_{S D}+W_{L S}+W_{S N}+W_{F}+W_{H}+W_{W}+W_{H P M}+W_{N D}+W_{C V}}(5)
$$

\subsubsection{LVI calculation based on framework of IPCC (LVI-IPCC)}

237 Vulnerability consider the function based on sensitivity, adaptive capacity and exposure about hazards according to IPCC, (2007) as explained below 
240 Such investigation related to vulnerability theories indicating as due to low adaptive capacity households are specifically vulnerable 241 (Adger, 2006; IPCC, 2007; Hoq et al., 2021). Exposure reports, specific location or environment of people influenced harmfully via 242 physical events as in this manner focus to possible future damages, harm or loss (Gasper, 2010). Sensitivity mentions degree to that 243 system is affected due to exposure whereas system's capacity to recover from exposure indicated as adaptive capacity (Ebi et al., 244 2006). There are various indicators composes to exposure, sensitivity and adaptive capacity. In the current era, numerous studies in 245 world scenario employed index based method for vulnerability measurement (Shah et al., 2013; Gasper, 2010; Hahn et al., 2009; 246 Toufique and Islam, 2014; Aryal et al., 2014). On the basis of equation 6, IPCC three factors adaptive capacity, exposure and 247 sensitivity were deliberated.

$$
C F_{d}=\frac{\sum_{i=1}^{n} w_{M C d i} M C_{d i}}{\sum_{i=1}^{n} w_{M C d i}}
$$

Adaptive capacity, exposure and sensitivity as three contributing factors of IPCC indicated as $\mathrm{CF}_{\mathrm{d}}$, whereas d explains district, district $\mathrm{d}$ major component elaborated as $\mathrm{MC}_{\mathrm{di}}$, while major components weights explained as $\mathrm{w}_{\mathrm{MCdi}}$, and each contributors factors of major component numbers shown as n. In equation 7, exposure index was expressed with relevant two contributing factors as climate variability (CV) and natural disaster (ND)

$$
\operatorname{Index}(\operatorname{Exp})_{d}=\frac{W_{\exp 1} N D+W_{\text {exp } 2} C V}{W_{\text {exp } 1}+W_{\text {exp } 2}}
$$

In equation 7, district based exposure index indicated as Index $(\operatorname{Exp})_{\mathrm{d}}$, whereas major components climate variability and natural disasters weights were expressed such as $\mathrm{W}_{\exp 2}, \mathrm{~W}_{\exp 1}$. Water $(\mathrm{W})$, health $(\mathrm{H})$, food $(\mathrm{F})$ and production and housing means $(\mathrm{PHM})$ indicated major contributing factors of sensitivity for $\mathrm{d}$ districts as sensitivity index was expressed in equation 8 . 


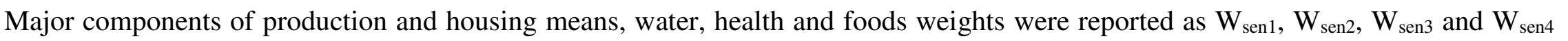
as highlighted in equation 8. In equation 9, socio-demographic factors (SD), livelihood strategies (LS) and social network (SN) were elaborated contributing factors of adaptive strategies index.

$$
\operatorname{Index}(\operatorname{adapt})_{d}=\frac{W_{\text {adapt } 1} S D+W_{\text {adapt } 2} L S+W_{\text {adapt } 3} S N}{W_{\text {adapt } 1}+W_{\text {adapt } 2}+W_{\text {adapt } 3}}
$$

These major components livelihood strategies, social network and socio-demographic are three contributing factors weights were

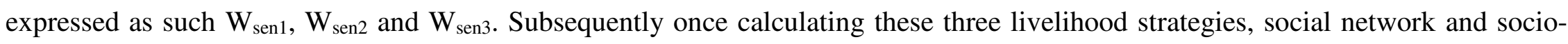
demographic contributing factors these were combined in equation 10.

$$
L V I-I P C C_{d}=\left[\operatorname{Index}(\operatorname{sen})_{d}-\operatorname{Index}(\operatorname{adpt})_{d}\right] * \operatorname{Index}(\exp )_{d}
$$

In using vulnerability framework of IPCC the LVI-IPCC was reported for LVI and district denoted for d, exposure calculated score for district $\mathrm{d}$ as Index $(\exp )_{\mathrm{d}}$, sensitivity for district $\mathrm{d}$ calculated score as Index $(\operatorname{sen})_{\mathrm{d}}$, and adaptive capacity for district $\mathrm{d}$ calculated score as Index $(\operatorname{adpt})_{\mathrm{d}}$. In LVI-IPCC were reported as scaled for most vulnerable +1 and least vulnerable -1 .

\section{Empirical results}

In LVI contributing factors of IPCC (sensitivity, exposure, adaptive capacity), major components (climate variability, natural disasters, food, water, health, production and housing means, livelihood strategies, social demographic factors, social network) and subcomponents, explanation, citation and expected association as indicated in table1.

\section{[Table 1]}


Three districts livelihood vulnerability unit measurement, maximum, minimum and actual values of subcomponents elaborated in table 2 whereas normalized sub-components and major components livelihood vulnerability indices of three districts explained in table 3. Contributing factors of IPCC and values of major factors are indicated in table 4 while major components indicated in spider figure 3 and LVI contributing factors triangle of three districts also highlighted in figure 4.

3.1 Influences of sub-components and major components on overall LVI of the Bait household among the districts

Three districts each sub-component livelihood vulnerability indices minimum, maximum and actual values are illustrated in table 2. Muzaffargarh Bait community have to travel (178.91 min) average time which is more than Rajanpur (169.87 min) and Rahim Yar Khan (154.01 min) Bait communities for health access as indicated in table 2. Access of latrine indicated significant sub-component of health as highlighting Bait communities' socioeconomic conditions as limited number of household in Rahim Yar Khan (31\%) Rajanpur (39\%) and Muzaffargarh (43\%) have access of sanitary latrine showing vulnerable scenario as elaborated in table 2. Muzaffargarh Bait community (3.4 month) have to struggle more for access sufficient food rather than Rajanpur (3.1 month) and Rahim Yar Khan (2.3 month) indicating higher vulnerable scenario of sufficient food access. Majority community in Muzaffargarh $(89 \%)$ worried about sufficient food rather than Rajanpur (83\%) and Rahim Yar Khan (78\%) whereas average index of diversifying crop (0.48) similar in three districts explained in table 2.

\section{[Table 2]}

In Muzaffargarh (27\%) Bait community having higher conflicts of water in community rather than Rajanpur (24\%) and Rahim Yar Khan (19\%). Higher proportion of Muzaffargarh (31\%) community use unsafe water rather than Rajanpur (28\%) and Rahim Yar Khan (23\%) and have to travel 5.7 minutes, 4.9 minutes and 3.8 minutes to access safe water as indicated in table 2. Majority of Bait communities in Muzaffargarh (68\%), Rajanpur (67\%) and Rahim Yar Khan (66\%) have access of own tubewell for water.

3.2 Overall inter-districts households sub-components and major components Livelihood Vulnerability indices (LVI) 
In table 3 major components vulnerability indices ranged 0.158 to 0.760 as these indices were compared among Bait communities of three study areas districts. In district based vulnerability scenario, Muzaffargarh was indicated higher vulnerable for climate variability (0.635), natural disasters $(0.501)$, food (0.515), health (0.460), production and housing means $(0.760)$, livelihood strategy $(0.403)$ and social network (0.424) whereas lower level of vulnerability estimated regarding the social demographic (0.158) and water (0.360) as results are same with the studies of Shah et al., (2013), Hussain et al., (2019), Elahi et al., (2021) and Hoq et al., (2021). In reviewing major components in scenario of sub-components Muzaffargarh district consider higher vulnerable regarding in last 10 years, gradually facing increasing summer duration (0.890), increasing rainfall (0.830) and temperature (0.880), flood events in last ten years (0.816), food primarily from own farm (0.910), worried about insufficient food (0.890), during illness local doctor treatment access (0.960), without solid structure house (0.920), affected floods households (0.950) and agriculture major dependency (0.940) elaborated in table 3. Muzaffargarh geographical conditions such as riverine floods on both eastern (Chenab River) and western side (Indus River) of district caused its higher vulnerability rather than other districts (Abid et al., 2016; PDMA, 2017; Ahmad et al., 2021).

Bait communities of district Rajanpur regarding to major components were higher vulnerable on climate variability (0.602), production and housing means (0.737) and food (0.490) whereas lower vulnerable to social demographic factors (0.174) and water (0.337) as illustrated in table 3. In the scenario of sub-components Rajanpur Bait community was highly vulnerable to increasing summer duration (0.860), increasing temperature (0.830), food from own farm (0.890), insufficient food (0.830), local doctor access (0.930), household solid structure (0.890), flood affects (0.940) and agriculture major income source (0.930) whereas lower vulnerable to safe water access $(0.157)$, missing working days due to illness $(0.160)$ and local organization participation (0.140). In the scenario of vulnerability regarding major components and sub-components almost same trends were estimated in district Rahim Yar Khan as in Rajanpur district as indicated in table 3. In these three districts study areas, riverine floods severity causes' higher destruction of agriculture as threaten the major livelihood source of Bait inhabitant's households. Estimates of major components lowest and highest vulnerability are almost similar with the studies of Shah et al., (2013), Abid et al., (2016), Abbas et al., (2017) and Hoq et al., (2021). 
317 Livelihood Vulnerability Index nine major components aggregate weighted scores indicated as flood hazards caused Muzaffargarh 318 (0.471) most vulnerable rather than Rahim Yar Khan (0.430) and Rajanpur (0.452) districts. In the scenario of socio-demographic 319 factors Rahim Yar Khan (0.176) is higher vulnerable rather than Muzaffargarh (0.158) and Rajanpur (0.174) as indicated in table 3. In 320 livelihood strategy major components, Rahim Yar Khan (0.419) and Rajanpur (0.427) communities were higher vulnerable than 321 Muzaffargarh Bait inhabitants (0.403). In major component of health, Muzaffargarh (0.460) and Rajanpur (0.414) Bait communities 322 were higher vulnerable than Rahim Yar Khan (0.365) Bait community as these findings are in line with the studies of Hussain et al., 323 (2019) and Ahmad and Afzal, (2020).

324 In table 3, higher score of food vulnerability subsequent to combining food sub-components was estimated in Muzaffargarh (0.515) 325 rather than Rahim Yar Khan (0.438) and Rajanpur (0.490). In Muzaffargarh (0.360) higher vulnerability regarding water was estimated in contrast to Rajanpur (0.337) and Rahim Yar Khan (0.303). In the scenario of production and housing means and flood

327 hazards regarding major components as combination of sub-components Muzaffargarh (0.760) (0.501) and Rajanpur (0.737) (0.444) districts are higher vulnerable rather than Rahim Yar Khan (0.650) (0.386) as indicated in table 3. Bait communities of these three districts more vulnerable to natural disaster specifically riverine floods no access of disasters warning, faced consecutive death and injuries and water logging till many months as elaborated in table 3 as these finding are alike to studies of Ahmad et al., (2019),

331 Hussain et al., (2019), Ahmad and Afzal, (2020) and Hoq et al., (2021). Climate variability major components scores were higher among these three districts while Muzaffargarh (0.635) indicated higher vulnerable rather than Rajanpur (0.602) and Rahim Yar Khan (0.595). Major components combined LVI scores estimates are reported in figure 3 spider diagram

\section{[Figure 3]} community higher vulnerable in climate variability, natural disasters, food, health, production and housing means and water, Rajanpur 
337 districts more vulnerable in livelihood strategy whereas Rahim Yar Khan districts higher vulnerable in social networks and socio

338 demographic factors as illustrated in figure 3.

$339 \quad 3.3$ Vulnerability assessment through LVI-IPCC approach

340 The IPCC weighted score of contributing factors sensitivity, exposure, and adaptive capacity and overall LVI-IPCC are illustrated in

341 table 4. Vulnerability estimates indicated district Muzaffargarh (0.087) and Rajanpur (0.079) communities higher vulnerable rather

342 than Rahim Yar Khan (0.038). Economic activates and geographical hazards prone locations are significant factors to increasing

343 adaptive capacity and exposure of community. The lower adaptive capacity of Muzaffargarh (0.328) and Rajanpur (0.343) rather than

344 Rahim Yar Khan (0.362) is major cause of higher vulnerability in these both districts as these findings are similar with the studies of

345 Abbas et al., (2017), Hussain et al., (2019), Ahmad and Afzal, (2020) and Hoq et al., (2021). Bait community of district Muzaffargarh

346 higher exposure (0.568) of flood hazards and more sensitive (0.524) rather than other two districts more vulnerable among three

347 districts. District Rahim Yar Khan lower exposure (0.491), sensitivity (0.439) and relatively higher adaptive capacity (0.362) made it

348 less vulnerable rather than two districts. Rajanpur district due to higher intensity based on exposure $(0.523)$, sensitivity $(0.495)$ and

349 lower adaptive capacity (0.343) higher vulnerable rather than Rahim Yar Khan district as indicated table 4 as these findings are similar

350 with the studies of Ahmad and Afzal., (2020) and Elahi et al., (2021).

352 IPCC scores of contributing factors sensitivity, exposure and adaptive capacity illustrated in triangle figure 4 as ranging to higher 353 contributing factors 0.5 and lower contributing factors 0. Bait households of district Muzaffargarh more sensitive (0.524) and exposed 354 (0.568) to climate variability, climate change and floods disasters as lower adaptive capacity caused higher vulnerable rather than 355 other two districts as elaborated in triangle figure 4. 


\section{Discussion}

358 In measuring Bait households vulnerabilities about climate change, climate driven natural hazards and flood disasters, this research work used major components, related indicators of LVI and contributing factors (adaptive capacity, sensitivity, exposure) of IPCC.

360 For proper understanding the influence of these indicators and components about livelihood vulnerability is crucial (Tran et al., 2020;

361 Hahn et al., 2009) for applying adaptation strategies, coping climate variability and future research for developing countries more specific like Pakistan (Ahmad et al., 2021). Estimates of the study indicated some minimal similarities and some significant vulnerability difference among these three Bait community districts study areas have specifically highlighted.

Some significant vulnerability differences among districts are indicated as firstly according to estimates of both LVI-IPCC and overall LVI, Muzaffargarh rather than other two districts indicated most vulnerable district due to facing consecutive riverine floods from western side Indus river and eastern side Chenab river. These both neighbouring rivers causes to increase vulnerability of this area as major destruction of agriculture crops specifically cotton crop, losses of livestock and available infrastructure as communities' livelihood becomes more vulnerable as similar liking indicated in literature studies Sujakhu et al., (2019) and Ahmad et al., (2021). Secondly vulnerability difference among districts is health services access indicated as significant indicator about livelihood vulnerability whereas Muzaffargarh and Rajanpur districts are higher vulnerable due to limited health services access as illustrated with consistent trends of literature (Alam et al., 2017). The reason is that Bait communities of Muzaffargarh and Rajanpur districts

372 have limited access of treatment from certified doctors due far areas from main city whereas Rahim Yar Khan Bait community higher access to certified doctors treatment due to located neighbouring of main city so location advantage causes the access of health services as findings shows same trends regarding literature Hussain et al., (2019) and Elahi et al., (2021). Thirdly, Bait community of district Muzaffargarh in contrast to other districts more involved in chronic diseases and illness and have to leave their work in last two weeks the reason of inadequate advanced health treatment facilities. These results illustrated the same development alike with 
vulnerability indicated in Muzaffargarh Bait community to find food, inhabitants have to struggles almost 3.4 month causes worry to sufficient food as these results illustrated the similar leaning regarding the literature Panthi et al., (2016), Abid et al., (2016) and Hussain et al., (2019).

Estimates of the study indicated some significant similarities among three districts firstly higher vulnerable scenario among three districts was indicated regarding component of social network. The reason is of limited access and participation to community based and social organizations such as political or farmers' organizations as these trends are related to literature Abid et al., (2016), Abbas et al., (2017) and Ahmad et al., (2019). Active participation in social structure is prerequisite to minimize vulnerability and boost up adaptive capacity of farming community (Agrawal, 2010). Secondly, among these districts is low literacy rate which causes to less awareness; limited information and limited earning due to inadequate education consider major factors of higher vulnerability in these communities (Ahmad et al., 2021). Thirdly, in these three districts Bait communities almost $67 \%$ households have no sanitary toilets as causes to increase health vulnerability that is because of river erosion, floods, land scarcity, inadequate roads networks and standing water bodies as findings have same tendency with literature Sujakhu et al., (2019). Fourthly, these three districts have same crop diversity index as apparent from food components thus limited number of Bait households engaged homestead, gardening, seed storage and food management practice which causes to increase vulnerability among Bait communities' households as estimates same liking with literature Ahmad et al., (2019) and Elahi et al., (2021). Lastly, among districts majority of Bait households due to lack of money and inadequate building material higher vulnerable to flood hazards and monsoon rain as their houses become fully or partially damage which causes to poor shelter and overall lower living. Bait households also reported as during couple of decades, due to consecutive flood hazards and erratic monsoon badly destructed their farming and fishery as these findings showed similar liking with literature Hussain et al., (2019), Ahmad and Afzal, (2020) and Elahi et al., (2021).

Households those engaged in off-farm activities moving outside Bait areas for earning and generating external income sources becomes less vulnerable to these hazards as these inclination similar with the literature Nhacolo et al., (2006), Islam et al., (2011), 
Sujakhu et al., (2019) and Hoq et al., (2021). In some limited measures of water storages from Pakistan's government caused at some extent decrease vulnerability of Bait communities as they become less vulnerable to flood disasters as compared to previous decades of these three districts. In summarizing the all major components Muzaffargarh reported as most vulnerable rather than Rahim Yar Khan and Rajanpur as these trends supported in literature by PDMA, (2014) and Ahmad et al., (2021).

\section{Conclusion and suggestions}

Bait communities of southern Punjab Pakistan are higher vulnerable due to their low lying geographical scenario in this region. In Bait areas, agricultural land consecutively remains under affect of flood hazards and erratic rains which causes to crop losses and infrastructural destructions such severe affects causes' household livelihood more vulnerable. This study focused to investigate Bait household's vulnerability of flood hazards owing to effect of change in worldwide temperature by using the LVI. Major components computed on the whole LVI illustrates as Bait community of Muzaffargarh (0.471) indicated more susceptible to flood disaster rather than Rajanpur (0.452) and Rahim Yar Khan (0.430). The index of LVI-IPCC also explained as Muzaffargarh (0.087) Bait community farming households were most vulnerable of flood disasters rather than Rajanpur (0.079) and Rahim Yar Khan (0.038).

In the scenario of study findings some significant suggestions are recommended to cope from flood disasters damages to Bait floodprone areas. Firstly, government needs to construct more water reserves specifically on major rivers as almost in 74 years history of country two major dams Terbela (1984) and Mangla (1967) were constructed. Increasing water reserves will multiple benefits with reducing floods consistency in flood prone areas, additional land available for cultivation, more access of irrigation water for agriculture and increasing hydropower generation. Secondly, on State basis there is need adopt proper strategies through streamlining related institutions such as local based disaster management authority, agriculture and weather department in advance get ready farmers to put into practice appropriate strategically measures to avoid flood induced vulnerabilities. Proper guidance, inspiration and anti disaster services need to provide farmers for adaptation of pro-active measures and improving farmers resilience from flood hazards. Thirdly, State based proper policy measures for development of overhead infrastructure and more opportunities for 
421 access to neighbouring towns and quick escape from riverine area to safe places during flood disasters emergency. Fourthly, 422 developed communication access and social links among society through social organization participation facilitates farmers to fast 423 livelihood recoveries of health, education, sanitation and livelihood activities. Fifthly, disaster concerned authorities need to focus on 424 preparedness plan of community and early warning system that may helpful these flood-prone areas to improving and increasing 425 services access of Bait communities regarding extreme weather preparation with purpose to reducing ecological variations 426 vulnerabilities. Lastly while more significant as Government must specifically introduce some suitable policy measures for minimum 427 interest based loans for technical and financial assistance to flood prone Bait household farmers for facilitating in flood disasters 428 adaptation measures. In this scenario such expectations can generated as LVI components will supportive to policy marker in 429 evaluating the livelihood vulnerability to climate change impacts and develop programmes and strengthen the vulnerable sectors of 430 Bait communities of southern Punjab of Pakistan.

\section{Declarations}

432 Ethical Approval

433 Ethical approval taken from the COMSATS University Vehari campus, ethical approval committee

434 Consent to Participate

435 Not applicable

436 Consent to Publish

437 Not applicable

438 Authors Contributions

439 DA analyzed data, methodology, results and discussion, conclusion and suggestions and manuscript write up whereas both DA and 440 MA finalized and proof read the manuscript and both authors read and approved the final manuscript. 
442 This study has no funding from any institution or any donor agency.

443 Competing Interests

444 The authors declare that they have no competing interest.

446 Availability of data and materials

447 The datasets used and/or analyzed during the current study are available from the corresponding author on reasonable request.

\section{References}

450

451

452

Abbas, G., Ahmad, S., Ahmad, A., Nasim, W., Fatima, Z., Hussain, S., ... \& Hoogenboom, G. (2017). Quantification the impacts of climate change and crop management on phenology of maize-based cropping system in Punjab, Pakistan. Agricultural and Forest Meteorology, 247, 42-55.

Abid, M., Schilling, J., Scheffran, J., \& Zulfiqar, F. (2016). Climate change vulnerability, adaptation and risk perceptions at farm level in Punjab, Pakistan. Science of the Total Environment, 547, 447-460.

Adger, W. N. (2006). Vulnerability. Global environmental change, 16(3), 268-281.

Agrawal, A. (2010). Local institutions and adaptation to climate change. Social dimensions of climate change: Equity and vulnerability in a warming world, 2, 173-178.

Ahmad, D., \& Afzal, M. (2020). Flood hazards and factors influencing household flood perception and mitigation strategies in Pakistan. Environmental Science and Pollution Research, 1-13.

Ahmad, D., \& Afzal, M. (2020). Flood hazards, human displacement and food insecurity in rural riverine areas of Punjab, Pakistan: policy implications. Environmental Science and Pollution Research, 1-15.

Ahmad, D., \& Afzal, M. (2021). Impact of climate change on pastoralists' resilience and sustainable mitigation in Punjab, Pakistan. Environment, Development and Sustainability, 1-21. 
Ahmad, D., Afzal, M., \& Rauf, A. (2019). Analysis of wheat farmers' risk perceptions and attitudes: evidence from Punjab, Pakistan. Natural Hazards, 95(3), 845-861.

Ahmad, D., Afzal, M., \& Rauf, A. (2021). Flood hazards adaptation strategies: a gender-based disaggregated analysis of farmdependent Bait community in Punjab, Pakistan. Environment, Development and Sustainability, 23(1), 865-886.

Ahmad, S., Abbas, G., Ahmed, M., Fatima, Z., Anjum, M. A., Rasul, G., ... \& Hoogenboom, G. (2019). Climate warming and management impact on the change of phenology of the rice-wheat cropping system in Punjab, Pakistan. Field crops research, 230, 46-61.

Al Baky, M. A., Islam, M., \& Paul, S. (2020). Flood hazard, vulnerability and risk assessment for different land use classes using a flow model. Earth Systems and Environment, 4(1), 225-244.

Alam, G. M., Alam, K., \& Mushtaq, S. (2017). Climate change perceptions and local adaptation strategies of hazard-prone rural households in Bangladesh. Climate Risk Management, 17, 52-63.

Ali, A., \& Rahut, D. B. (2020). Localized floods, poverty and food security: empirical evidence from rural Pakistan. Hydrology, 7(1), 2.

Ali, K. F., \& De Boer, D. H. (2010). Spatially distributed erosion and sediment yield modeling in the upper Indus River basin. Water Resources Research, 46(8).

Amin, A., Nasim, W., Mubeen, M., Sarwar, S., Urich, P., Ahmad, A., ... \& Ali, Q. S. (2018). Regional climate assessment of precipitation and temperature in Southern Punjab (Pakistan) using SimCLIM climate model for different temporal scales. Theoretical and Applied climatology, 131(1), 121-131.

Aryal, S., Cockfield, G., \& Maraseni, T. N. (2014). Vulnerability of Himalayan transhumant communities to climate change. Climatic Change, 125(2), 193-208.

Ashraf, M., \& Shakir, A. S. (2018). Prediction of river bank erosion and protection works in a reach of Chenab River, Pakistan. Arabian Journal of Geosciences, 11(7), 1-11. 
Bahadar, I., Shafique, M., Khan, T., Tabassum, I., \& Ali, M. Z. (2015). Flood hazard assessment using hydro-dynamic model and GIS/RS tools: A case study of Babuzai-Kabal tehsil Swat Basin, Pakistan. Journal of Himalayan Earth Science, 48(2).

Birkholz, S., Muro, M., Jeffrey, P., \& Smith, H. M. (2014). Rethinking the relationship between flood risk perception and flood management. Science of the Total Environment, 478, 12-20.

Board of Statistics (BOS) Punjab (2017) Agriculture Information Marketing Services (AIMS) Lahore, Punjab, Pakistan

Board of Statistics (BOS) Punjab (2018) Agriculture Information Marketing Services (AIMS) Lahore, Punjab, Pakistan

Board of Statistics (BOS) Punjab (2019). Punjab statistics 2019, Statistical Division Punjab Government of Punjab, Lahore, Punjab, Pakistan

Bokhari, S. A. A., Ahmad, B., Ali, J., Ahmad, S., Mushtaq, H., \& Rasul, G. (2018). Future climate change projections of the Kabul River Basin using a multi-model ensemble of high-resolution statistically downscaled data. Earth Systems and Environment, 2(3), 477-497.

Can, N. D., Tu, V. H., \& Hoanh, C. T. (2013). Application of livelihood vulnerability index to assess risks from flood vulnerability and climate variability-A case study in the Mekong Delta of Vietnam. Journal of Environmental Science and Engineering. A, 2(8A), 476.

Cochran WG (1977) Double sampling. In: Cochran WG (ed) Sampling techniques, 3rd edn. Wiley, New York, pp 327-358

Daniell, H., Lin, C. S., Yu, M., \& Chang, W. J. (2016). Chloroplast genomes: diversity, evolution, and applications in genetic engineering. Genome biology, 17(1), 1-29.

Ebi, K. L., Kovats, R. S., \& Menne, B. (2006). An approach for assessing human health vulnerability and public health interventions to adapt to climate change. Environmental health perspectives, 114(12), 1930-1934.

Eckstein, D., Künzel, V., Schäfer, L., \& Winges, M. (2019). Global climate risk index 2020. Bonn: Germanwatch. 
Elahi, E., Khalid, Z., Tauni, M. Z., Zhang, H., \& Lirong, X. (2021). Extreme weather events risk to crop-production and the adaptation of innovative management strategies to mitigate the risk: A retrospective survey of rural Punjab, Pakistan. Technovation, 102255.

Emergency Event Database (2017) The International Disaster Database, Emergency Event Database (EE-DAT), 2017

Etwire, P. M., Al-Hassan, R. M., Kuwornu, J. K., \& Osei-Owusu, Y. (2013). Application of livelihood vulnerability index in assessing vulnerability to climate change and variability in Northern Ghana. Journal of Environment and Earth Science, 3(2), 157-170.

Gasper, D. (2010). The idea of human security.

Gaurav, K., Sinha, R., \& Panda, P. K. (2011). The Indus flood of 2010 in Pakistan: a perspective analysis using remote sensing data. Natural hazards, 59(3), 1815-1826.

GOP (2020) Economic Survey of Pakistan 2019-20, Pakistan Bureau of Statistics, Ministry of Finance Government of Pakistan. http://www.finance.gov.pk/survey_1920.html

Gorst, A., Dehlavi, A., \& Groom, B. (2018). Crop productivity and adaptation to climate change in Pakistan. Environment and development economics, 23(6), 679-701.

Hahn, M. B., Riederer, A. M., \& Foster, S. O. (2009). The Livelihood Vulnerability Index: A pragmatic approach to assessing risks from climate variability and change-A case study in Mozambique. Global environmental change, 19(1), 74-88.

Hashmi, H. N., Siddiqui, Q. T. M., Ghumman, A. R., \& Kamal, M. A. (2012). A critical analysis of 2010 floods in Pakistan. African Journal of Agricultural Research, 7(7), 1054-1067.

Hirabayashi, Y., Mahendran, R., Koirala, S., Konoshima, L., Yamazaki, D., Watanabe, S., ... \& Kanae, S. (2013). Global flood risk under climate change. Nature Climate Change, 3(9), 816-821.

Hoq, M. S., Raha, S. K., \& Hossain, M. I. (2021). Livelihood vulnerability to flood hazard: understanding from the flood-prone Haor Ecosystem of Bangladesh. Environmental management, 1-21. 
Huong, N. T. L., Yao, S., \& Fahad, S. (2019). Assessing household livelihood vulnerability to climate change: The case of Northwest Vietnam. Human and Ecological Risk Assessment: An International Journal, 25(5), 1157-1175.

Hussain, M., Butt, A. R., Uzma, F., Ahmed, R., Rehman, A., Ali, M. U., ... \& Yousaf, B. (2019). Divisional disparities on climate change adaptation and mitigation in Punjab, Pakistan: local perceptions, vulnerabilities, and policy implications. Environmental Science and Pollution Research, 26(30), 31491-31507.

IPCC (2001) Climate change 2001: impacts, adaptation, and vulnerability. Contribution of Working Group II to the Third Assessment Report. Intergovernmental Panel on Climate Change (IPCC). Cambridge University Press, Cambridge, UK. p 1055-

IPCC (2014) Climate change 2014: synthesis report. Contribution of Working Groups I, II and III to the Fifth Assessment Report. Intergovernmental Panel on Climate Change (IPCC). Cambridge University Press, Cambridge, UK. p 1055

IPCC, (2007). climate change 2007: impacts, adaptation and vulnerability. Contribution of working group II to the fourth assessment report of the intergovernmental panel on climate change. Cambridge Uni-versity Press, Cambridge, UK.

Islam, S., Uddin, M. T., Rahman, M., \& Haque, M. A. (2011). Profitability of alternate farming systems in Dingapota haor area of Netrokona district. Progressive Agriculture, 22(1-2), 223-239.

James, E. (2008). Getting ahead of the next disaster: recent preparedness efforts in Indonesia. Development in Practice, 18(3), 424429.

Khan, A. A., \& Ali, S. B. (2003). Effects of erosion on Indus River bio-diversity in Pakistan. Pakistan Journal of Biological Sciences, 6(12), 1035-1040.

Khan, A. N. (2011). Analysis of flood causes and associated socio-economic damages in the Hindukush region. Natural hazards, 59(3), 1239.

Khan, A. N. (2013). Analysis of 2010-flood causes, nature and magnitude in the Khyber Pakhtunkhwa, Pakistan. Natural hazards, 66(2), 887-904. 
Khan, H. U. A., Khalil, S. F. A., Kazmi, S. J. H., Umar, M., Shahzad, A., \& Farhan, S. B. (2017). IDENTIFICATION OF RIVER BANK EROSION AND INUNDATION HAZARD ZONES USING GEOSPATIAL TECHNIQUES-A CASE STUDY OF INDUS RIVER NEAR LAYYAH DISTRICT, PUNJAB, PAKISTAN. Geoplan J Geomat Plan, 4, 121-130.

Kotrlik, J. W. K. J. W., \& Higgins, C. C. H. C. C. (2001). Organizational research: Determining appropriate sample size in survey research appropriate sample size in survey research. Information technology, learning, and performance journal, $19(1), 43$.

Krausmann, E., \& Mushtaq, F. (2008). A qualitative Natech damage scale for the impact of floods on selected industrial facilities. Natural Hazards, 46(2), 179-197.

Leichenko, R. M., \& Wescoat Jr, J. L. (1993). Environmental impacts of climate change and water development in the Indus delta region. International Journal of Water Resources Development, 9(3), 247-261.

López-Marrero, T., \& Yarnal, B. (2010). Putting adaptive capacity into the context of people's lives: a case study of two flood-prone communities in Puerto Rico. Natural hazards, 52(2), 277-297.

Mahmood, R., Jia, S., \& Babel, M. S. (2016). Potential impacts of climate change on water resources in the Kunhar River Basin, Pakistan. Water, 8(1), 23.

Nazli, H., Orden, D., Sarker, R., \& Meilke, K. D. (2012). Bt cotton adoption and wellbeing of farmers in Pakistan (No. 1007-201679742).

NDMA, Pakistan (2018) Annual Report 2018, National Disaster Management Authority Pakistan. http://www.ndma.gov.pk/

Nhacolo, A. Q., Nhalungo, D. A., Sacoor, C. N., Aponte, J. J., Thompson, R., \& Alonso, P. (2006). Levels and trends of demographic indices in southern rural Mozambique: evidence from demographic surveillance in Manhica district. BMC public health, 6(1), $1-13$.

Osberghaus, D. (2015). The determinants of private flood mitigation measures in Germany-Evidence from a nationwide survey. Ecological Economics, 110, 36-50. 
Panthi, J., Aryal, S., Dahal, P., Bhandari, P., Krakauer, N. Y., \& Pandey, V. P. (2016). Livelihood vulnerability approach to assessing climate change impacts on mixed agro-livestock smallholders around the Gandaki River Basin in Nepal. Regional Environmental Change, 16(4), 1121-1132.

Paul, S. K., \& Routray, J. K. (2010). Flood proneness and coping strategies: the experiences of two villages in Bangladesh. Disasters, 34(2), 489-508.

PBS (2010). Agricultural Census 2010, Pakistan Bureau of Statistics, Ministry of Finance Statistical Division, Government of Pakistan https://www.pbs.gov.pk/agriculture-census-publications

PBS (2017) 6TH Population and Housing Census (2017) Pakistan Bureau of Statistics, Ministry of Finance, Government of Pakistan

PBS (2019). Economic Survey of Pakistan 2018-2019 Pakistan Bureau of Statistics, Ministry of Finance Statistical Division, Government of Pakistan

PDMA Punjab (2017) Annual Report 2017, Provincial Disaster Management Authority Punjab Pakistan. https://pdma.punjab.gov

PDMA, Punjab (2014) Monsoon Contingency Plan Punjab 2014, Punjab Provincial Disaster Management Authority (PDMA) Government of Punjab, Pakistan.

pk/system/files/Annual\%20Report\%202017_0.pdf\#overlay-context=node/438

PMD, (2019). Monthly weather report, 2019. National weather forecasting centre pakistan meteorologcal department (PMD) Islamabad, Government of Pakistan. http://nwfc.pmd.gov.pk/new/asset s/month ly-weath er-repor ts/2019-08.pdf publications/Annual\%20Report\%202018.pdf

Qayyum, A., Khan, J. A., Hussain, R., Avais, M., Ahmed, N., Khan, A., \& Khan, M. S. (2016). Prevalence and Association of Possible Risk Factors with Sub-Clinical Mastitis in Cholistani Cattle. Pakistan Journal of Zoology, 48(2).

Rafiq, L., \& Blaschke, T. (2012). Disaster risk and vulnerability in Pakistan at a district level. Geomatics, Natural Hazards and Risk, 3(4), 324-341. 
Rasul, G., Mahmood, A., Sadiq, A., \& Khan, S. I. (2012). Vulnerability of the Indus delta to climate change in Pakistan. Pakistan journal of meteorology, $8(16)$.

Sarker, M. N. I., Wu, M., Alam, G. M., \& Shouse, R. C. (2019). Livelihood vulnerability of riverine-island dwellers in the face of natural disasters in Bangladesh. Sustainability, 11(6), 1623.

Shah, A. A., Ye, J., Shaw, R., Ullah, R., \& Ali, M. (2020). Factors affecting flood-induced household vulnerability and health risks in Pakistan: the case of Khyber Pakhtunkhwa (KP) Province. International Journal of Disaster Risk Reduction, 42, 101341.

Shah, K. U., Dulal, H. B., Johnson, C., \& Baptiste, A. (2013). Understanding livelihood vulnerability to climate change: Applying the livelihood vulnerability index in Trinidad and Tobago. Geoforum, 47, 125-137.

Singla S.and Sagar M. (2012): Integrated Risk Management in Agriculture: An Inductive Research. The Journal of Risk Finance, 13(3), 199-214. doi:10.1108/15265941211229235

Sujakhu, N. M., Ranjitkar, S., He, J., Schmidt-Vogt, D., Su, Y., \& Xu, J. (2019). Assessing the livelihood vulnerability of rural indigenous households to climate changes in Central Nepal, Himalaya. Sustainability, 11(10), 2977.

Sullivan, C. A., Meigh, J. R., \& Fediw, T. S. (2002). Derivation and testing of the water poverty index phase 1. Final report may 2002.

Tariq, M. A. U. R., \& Van De Giesen, N. (2012). Floods and flood management in Pakistan. Physics and Chemistry of the Earth, Parts $A / B / C, 47,11-20$.

Tariq, M., Ahmad, S., Fahad, S., Abbas, G., Hussain, S., Fatima, Z., ... \& Hoogenboom, G. (2018). The impact of climate warming and crop management on phenology of sunflower-based cropping systems in Punjab, Pakistan. Agricultural and Forest Meteorology, 256, 270-282.

Teo, M., Goonetilleke, A., Ahankoob, A., Deilami, K., \& Lawie, M. (2018). Disaster awareness and information seeking behaviour among residents from low socio-economic backgrounds. International journal of disaster risk reduction, 31, $1121-1131$.

Tewari, H. R., \& Bhowmick, P. K. (2014). Livelihood vulnerability index analysis: An approach to study vulnerability in the context of Bihar. 
Tjoe, Y. (2016). Measuring the livelihood vulnerability index of a dry region in Indonesia. World Journal of Science, Technology and Sustainable Development.

Toufique, K. A., \& Islam, A. (2014). Assessing risks from climate variability and change for disaster-prone zones in Bangladesh. International Journal of Disaster Risk Reduction, 10, 236-249.

Tran, D. D., Quang, C. N. X., Tien, P. D., Tran, P. G., Kim Long, P., Van Hoa, H., ... \& Le Ha, T. T. (2020). Livelihood Vulnerability and Adaptation Capacity of Rice Farmers under Climate Change and Environmental Pressure on the Vietnam Mekong Delta Floodplains. Water, 12(11), 3282.

UNDP (2007) Human development reports. http://hdr.undp.org/en/Accessed 25 Dec 2007

UNDP (2019) United Nations Development Programme in Pakistan Annual Report 2018. file://C:/Users/ACS/Downloads/UNDPPakistan-AnnualReport2018.pdf

United Nations (2011) Pakistan floods: one year on 2011. A Report by the United Nations-Pakistan, Islamabad. http://unportal.un.org.pk/sites/unpakistan/pages/default.aspx. Accessed 7 Aug 2013

Wilby, R. L., \& Keenan, R. (2012). Adapting to flood risk under climate change. Progress in physical geography, 36(3), $348-378$.

Wisner, B., Blaikie, P., Blaikie, P. M., Cannon, T., \& Davis, I. (2004). At risk: natural hazards, people's vulnerability and disasters. Psychology Press.

World Bank. (2013). Turn down the heat: Climate extremes, regional impacts, and the case for resilience.

Yaqub, M., Beytullah, E. R. E. N., \& Doğan, E. (2015). Flood causes, consequences and protection measures in Pakistan. Disaster Science and Engineering, 1(1), 8-16.

Zhang, S., Hua, D., Meng, X., \& Zhang, Y. (2011). Climate change and its driving effect on the runoff in the "Three-River Headwaters" region. Journal of Geographical Sciences, 21(6), 963-978. 
634 Table 1 Livelihood vulnerability index making up through construction of sub-components and major components

\begin{tabular}{|c|c|c|c|c|}
\hline $\begin{array}{l}\text { Contributing } \\
\text { factors of IPCC }\end{array}$ & $\begin{array}{l}\text { Study } \\
\text { major } \\
\text { compone } \\
\text { nts }\end{array}$ & Study sub-components & $\begin{array}{l}\text { Sub-components explanation with } \\
\text { citation }\end{array}$ & Expected associations \\
\hline \multirow[t]{10}{*}{$\begin{array}{l}\text { Adaptive } \\
\text { capacity }\end{array}$} & \multirow[t]{7}{*}{$\begin{array}{l}\text { Liveliho } \\
\text { od } \\
\text { strategy }\end{array}$} & $\begin{array}{l}\text { Dependency on } \\
\text { agriculture as major } \\
\text { income source }\end{array}$ & $\begin{array}{l}\text { Household percentage that having } \\
\text { depend on agriculture as main } \\
\text { income source (Alam, 2017) }\end{array}$ & Vulnerability increases with single dependency \\
\hline & & $\begin{array}{l}\text { Non-farm activates of } \\
\text { households affected by } \\
\text { natural disasters as floods }\end{array}$ & $\begin{array}{l}\text { Household percentage indicated as } \\
\text { non-farm activities were affected by } \\
\text { other hazards or floods (Alam, } \\
\text { 2017) }\end{array}$ & Vulnerability increases as non-farm activates affected by floods \\
\hline & & $\begin{array}{l}\text { Household percentage } \\
\text { those member or head } \\
\text { having opportunity of } \\
\text { training to cope of other } \\
\text { or flood disasters }\end{array}$ & $\begin{array}{l}\text { Household percentage those } \\
\text { member or head having training to } \\
\text { cope of other hazards or flood } \\
\text { disasters (Alam, 2017) }\end{array}$ & Vulnerability decreases with access of training \\
\hline & & $\begin{array}{l}\text { Average agricultural } \\
\text { livelihood diversification } \\
\text { index [as range }(0.20-1)]\end{array}$ & $\begin{array}{l}\text { Inverse of agricultural numbers } \\
\text { livelihood activities }+1 \text { indicated by } \\
\text { households as households that farm } \\
\text { raises livestock and having off-farm } \\
\text { activities will having livelihood } \\
\text { diversification index }=1 /(3+1)=0.25 \\
\text { (Huong et al., 2018) }\end{array}$ & $\begin{array}{l}\text { Higher the vulnerability as higher the agricultural diversification } \\
\text { index }\end{array}$ \\
\hline & & $\begin{array}{l}\text { Household percentage as } \\
\text { their member working in } \\
\text { various communities }\end{array}$ & $\begin{array}{l}\text { Household percentage indicating as } \\
\text { one of family member who } \\
\text { participate outside community } \\
\text { (Alam, 2017) }\end{array}$ & Vulnerability decreases as working in various communities increases \\
\hline & & $\begin{array}{l}\text { Household percentage } \\
\text { have job opportunities in } \\
\text { flood season }\end{array}$ & $\begin{array}{l}\text { Household percentage indicated } \\
\text { having job opportunities in flood } \\
\text { season }\end{array}$ & Vulnerability increases as unemployment increases \\
\hline & & $\begin{array}{l}\text { Household percentage } \\
\text { those fished in flood } \\
\text { season }\end{array}$ & $\begin{array}{l}\text { Household percentage having } \\
\text { opportunities to engaging in fishing } \\
\text { in flood season (Alam, 2017) }\end{array}$ & Household vulnerability decreases as fishing increases \\
\hline & \multirow{3}{*}{$\begin{array}{l}\text { Social } \\
\text { demogra } \\
\text { phic } \\
\text { factors }\end{array}$} & Dependency ratio & $\begin{array}{l}\text { Population ratio less than } 15 \text { and } \\
\text { more than } 65 \text { years (Shah et al., } \\
\text { 2013) }\end{array}$ & Vulnerability increases as dependency decreases \\
\hline & & $\begin{array}{l}\text { Household average family } \\
\text { number members }\end{array}$ & $\begin{array}{l}\text { In household family member } \\
\text { average number (Alam, 2017) }\end{array}$ & Vulnerability increases as higher number family members \\
\hline & & Female headed percentage & Household percentage headed by & Vulnerability increases as female head scenario increases \\
\hline
\end{tabular}




\begin{tabular}{|c|c|c|c|c|}
\hline & & & $\begin{array}{l}\text { female whether male away from } \\
\text { house almost } 6 \text { month as female } \\
\text { headed the household activities } \\
\text { (Hahn et al., 2009) }\end{array}$ & \\
\hline & & $\begin{array}{l}\text { Household head } \\
\text { percentage those not } \\
\text { attended schooling }\end{array}$ & $\begin{array}{l}\text { Household percentage those } \\
\text { indicated as no schooling (Adu et } \\
\text { al., 2018) }\end{array}$ & Vulnerability decreases as schooling increases \\
\hline & & $\begin{array}{l}\text { Literacy rate of } \\
\text { households }\end{array}$ & $\begin{array}{l}\text { In household peoples percentage } \\
\text { those can write and read, dividing } \\
\text { literate members in total } \\
\text { membership households and } \\
\text { multiply } 100 \text { (Zuroec et al., 2017) }\end{array}$ & Vulnerability increases as higher household family members \\
\hline & $\begin{array}{l}\text { Social } \\
\text { networks }\end{array}$ & $\begin{array}{l}\text { Borrowing average, } \\
\text { lending money ratio range } \\
\text { of }(0.20-1)\end{array}$ & $\begin{array}{l}\text { Household money borrowing ratio } \\
\text { to household money lending in } \\
\text { previous month, if household } \\
\text { borrow money while no lend is } \\
\text { ration } 2: 1 \text {, or } 2 \text { whereas if not } \\
\text { borrow while lend money ratio } 1: 2 \\
\text { as } 0.5 \text { (Shah et al., 2013) }\end{array}$ & Vulnerability decreases as higher ratio \\
\hline & & $\begin{array}{l}\text { Households percentage } \\
\text { those focus govt } \\
\text { institutions for assistance } \\
\text { in last twelve months }\end{array}$ & $\begin{array}{l}\text { Household percentage indicated as } \\
\text { they acquired local govt institutions } \\
\text { for assistance in last twelve months } \\
\text { (Hahn et al., 2009) }\end{array}$ & Vulnerability decreases as govt assistance to population increases \\
\hline & & $\begin{array}{l}\text { Household percentage } \\
\text { concerned organizations } \\
\text { of farmers }\end{array}$ & $\begin{array}{l}\text { Household percentage indicated as } \\
\text { they concerned to organizations of } \\
\text { farmers (Alam et al., 2017) }\end{array}$ & $\begin{array}{l}\text { Vulnerability decreases as increase farmers participation in farmers } \\
\text { organizations }\end{array}$ \\
\hline & & $\begin{array}{l}\text { Household percentage } \\
\text { concerned in political } \\
\text { organization scenario }\end{array}$ & $\begin{array}{l}\text { Household percentage indicated as } \\
\text { concerned in political organization } \\
\text { (Alam et al., 2017) }\end{array}$ & $\begin{array}{l}\text { Vulnerability decreases as participation of political organization } \\
\text { increases }\end{array}$ \\
\hline & & $\begin{array}{l}\text { Household percentage } \\
\text { concerned to social } \\
\text { organization scenario }\end{array}$ & $\begin{array}{l}\text { Household percentage indicated } \\
\text { connected with social organization } \\
\text { (Alam et al., 2017) }\end{array}$ & $\begin{array}{l}\text { Vulnerability decreases as household participation in social } \\
\text { organization increase }\end{array}$ \\
\hline Sensitivity & Food & $\begin{array}{l}\text { Insufficient food with } \\
\text { number of average month } \\
\text { in range }(0-12)\end{array}$ & $\begin{array}{l}\text { Households struggle to find food } \\
\text { number of average month (Sujakhu } \\
\text { et al., 2019) }\end{array}$ & Higher vulnerability as higher number of month \\
\hline & & $\begin{array}{l}\text { Household percentage } \\
\text { acquire food primarily } \\
\text { from own farm }\end{array}$ & $\begin{array}{l}\text { Household number get food from } \\
\text { their own farm (Shah et al., 2013) }\end{array}$ & Higher vulnerability as higher number of month \\
\hline & & $\begin{array}{l}\text { Index of diversifying } \\
\text { average crop range }(0-1)\end{array}$ & $\begin{array}{l}\text { Household grown inverse number of } \\
\text { crops }+1 \text { as those household grow }\end{array}$ & Higher vulnerability as higher index \\
\hline
\end{tabular}




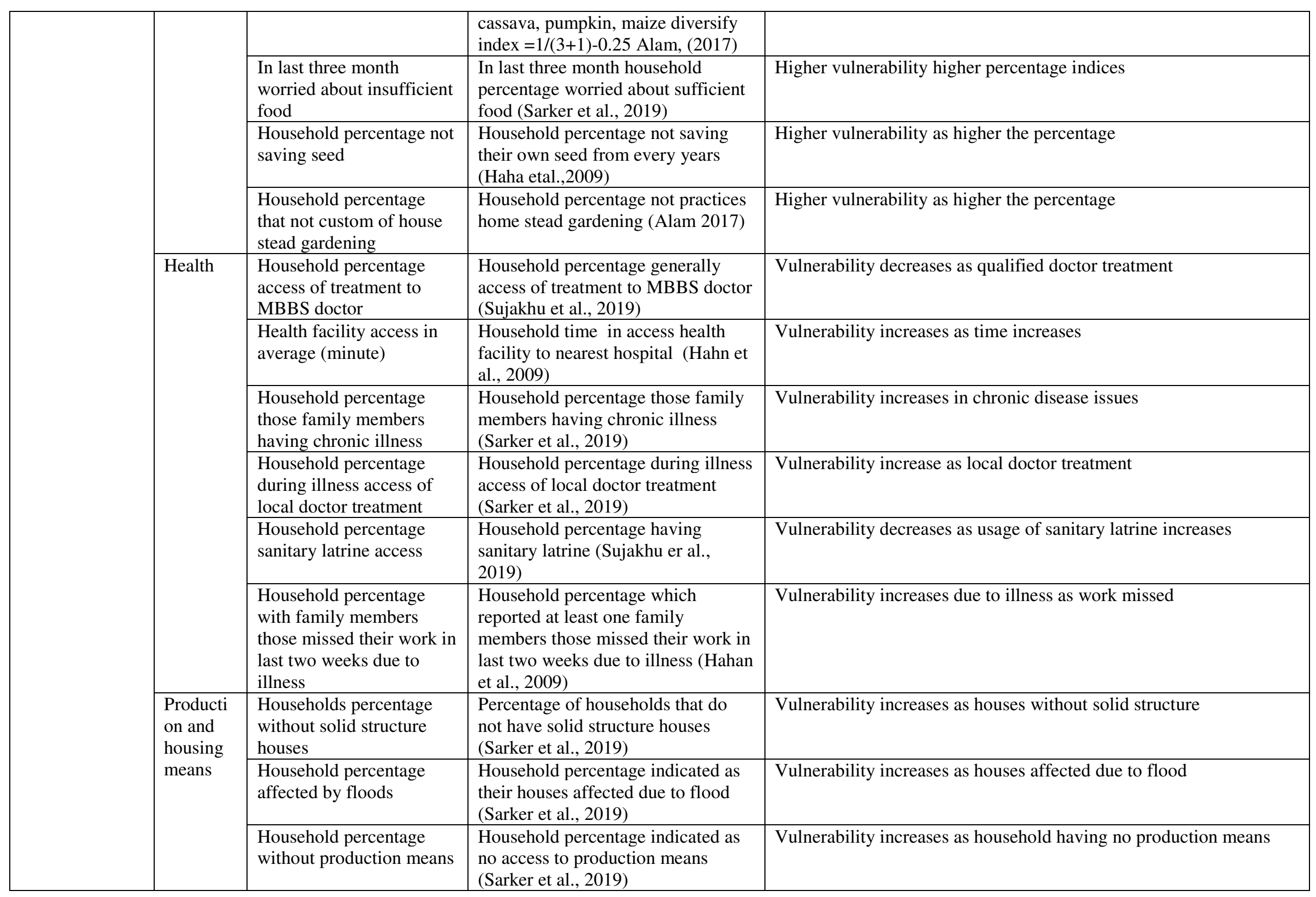




\begin{tabular}{|c|c|c|c|c|}
\hline & \multirow[t]{4}{*}{ Water } & $\begin{array}{l}\text { Household percentage } \\
\text { indicating community } \\
\text { based water conflicts }\end{array}$ & $\begin{array}{l}\text { Household percentage that } \\
\text { indicating having related } \\
\text { community based water conflicts } \\
\text { (Alam, 2017) }\end{array}$ & Higher vulnerability as higher conflicts in community \\
\hline & & $\begin{array}{l}\text { Household percentage } \\
\text { using unsafe or natural } \\
\text { water source }\end{array}$ & $\begin{array}{l}\text { Household percentage indicated as } \\
\text { lake and water ponds as basic } \\
\text { sources of water access (Hahn et al., } \\
2009 \text { ) }\end{array}$ & Higher vulnerability as drinking unsafe water \\
\hline & & $\begin{array}{l}\text { Average time in minutes } \\
\text { to access safe useable } \\
\text { water from sources }\end{array}$ & $\begin{array}{l}\text { Household require time to access } \\
\text { water from primary source (Alam, } \\
\text { 2017) }\end{array}$ & Vulnerability increases as time to access water increases \\
\hline & & $\begin{array}{l}\text { Household percentage } \\
\text { access easily water from } \\
\text { tubewell }\end{array}$ & $\begin{array}{l}\text { Household percentage having their } \\
\text { own water sources (Sarker et al., } \\
\text { 2019) }\end{array}$ & Vulnerability decreases as own water sources increases \\
\hline \multirow[t]{9}{*}{ Exposure } & \multirow[t]{9}{*}{$\begin{array}{l}\text { Climate } \\
\text { variabilit } \\
\text { y }\end{array}$} & $\begin{array}{l}\text { In last } 10 \text { years, gradually } \\
\text { facing increasing summer } \\
\text { duration }\end{array}$ & $\begin{array}{l}\text { Households percentage reported } \\
\text { increasing duration of summer in } 10 \\
\text { years (Sarker et al., 2019) }\end{array}$ & Facing increasing vulnerability due to increasing duration in summer \\
\hline & & $\begin{array}{l}\text { In last } 10 \text { years, gradually } \\
\text { facing increasing winter } \\
\text { duration }\end{array}$ & $\begin{array}{l}\text { Households percentage reported } \\
\text { increasing duration of winter in } 10 \\
\text { years (Sarker et al., 2019) }\end{array}$ & Facing increasing vulnerability due to increasing duration in winter \\
\hline & & $\begin{array}{l}\text { In last } 10 \text { years, gradually } \\
\text { facing increasing winter } \\
\text { season rainfall }\end{array}$ & $\begin{array}{l}\text { Households percentage reported } \\
\text { increasing winter season rainfall in } \\
10 \text { years (Sarker et al., 2019) }\end{array}$ & $\begin{array}{l}\text { Facing increasing vulnerability due to increasing winter season } \\
\text { rainfall }\end{array}$ \\
\hline & & $\begin{array}{l}\text { In last } 10 \text { years, gradually } \\
\text { facing increasing } \\
\text { monsoon rainfall }\end{array}$ & $\begin{array}{l}\text { Households percentage reported } \\
\text { increasing monsoon rainfall in } 10 \\
\text { years (Sarker et al., 2019) }\end{array}$ & Facing increasing vulnerability due to increasing monsoon rainfall \\
\hline & & $\begin{array}{l}\text { In last } 10 \text { years, gradually } \\
\text { facing increasing rainfall }\end{array}$ & $\begin{array}{l}\text { Households percentage reported } \\
\text { increasing rainfall in last } 10 \text { years } \\
\text { (Sarker et al., 2019) }\end{array}$ & Facing increasing vulnerability due to increasing heavy rainfall \\
\hline & & $\begin{array}{l}\text { In last } 10 \text { years, gradually } \\
\text { facing increasing } \\
\text { occurrence of hailstorm }\end{array}$ & $\begin{array}{l}\text { Households percentage reported } \\
\text { increasing occurrence of hailstorm } \\
\text { in last } 10 \text { years (new) }\end{array}$ & $\begin{array}{l}\text { Facing increasing vulnerability due to increasing occurrence of } \\
\text { hailstorm }\end{array}$ \\
\hline & & $\begin{array}{l}\text { In last } 10 \text { years, gradually } \\
\text { facing increasing } \\
\text { occurrence of riverbank } \\
\text { erosion }\end{array}$ & $\begin{array}{l}\text { Households percentage reported } \\
\text { increasing occurrence of riverbank } \\
\text { erosion in last } 10 \text { years (Alam, } \\
\text { 2017) }\end{array}$ & $\begin{array}{l}\text { Facing increasing vulnerability due to increasing occurrence of } \\
\text { riverbank erosion }\end{array}$ \\
\hline & & $\begin{array}{l}\text { In last } 10 \text { years, gradually } \\
\text { facing increasing } \\
\text { temperature }\end{array}$ & $\begin{array}{l}\text { Households percentage reported } \\
\text { increasing temperature in last } 10 \\
\text { years (Alam, 2017) }\end{array}$ & Facing increasing vulnerability due to increasing temperature \\
\hline & & In last 10 years, gradually & Households percentage reported & Facing increasing vulnerability due to increasing floodwater \\
\hline
\end{tabular}




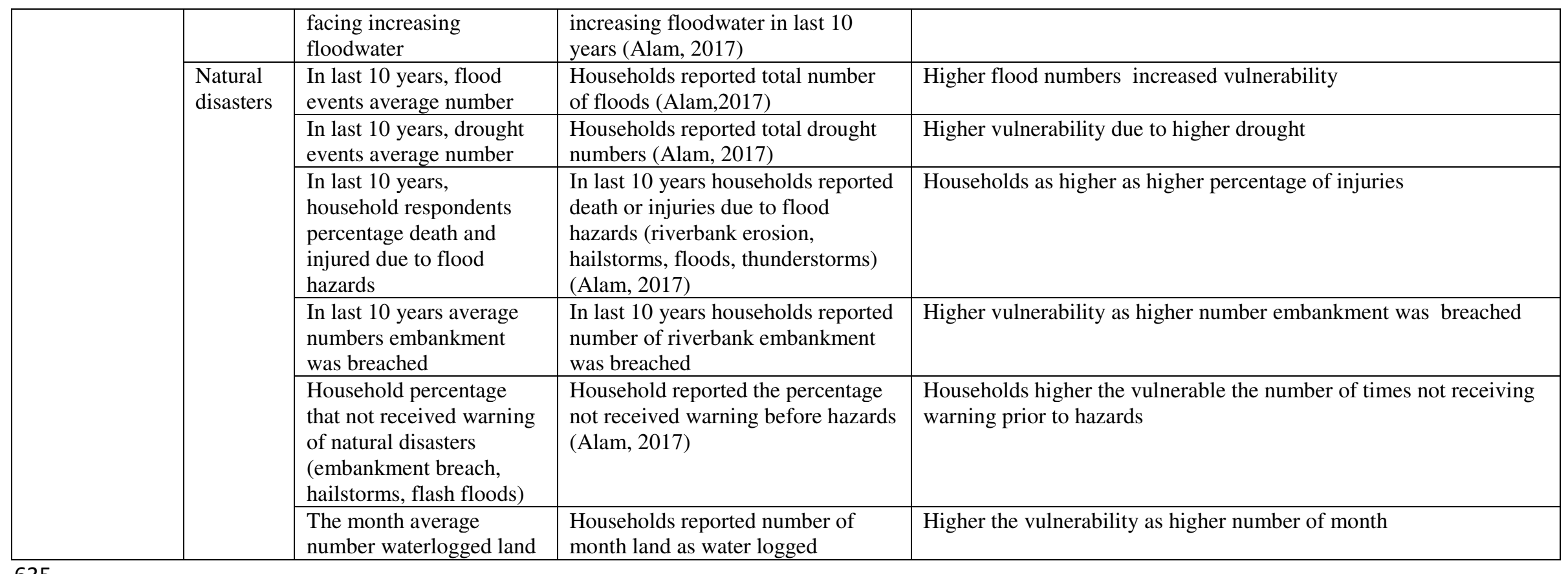


649 Table 2 Three districts each sub-component livelihood vulnerability indices minimum, maximum and actual values

\begin{tabular}{|c|c|c|c|c|c|c|c|}
\hline $\begin{array}{l}\text { LVI major } \\
\text { components }\end{array}$ & LVI sub-components & $\begin{array}{l}\text { Measurem } \\
\text { ent unit }\end{array}$ & $\begin{array}{l}\text { Muzaffargarh } \\
\text { district }\end{array}$ & $\begin{array}{l}\text { Rahim Yar } \\
\text { Khan } \\
\text { district }\end{array}$ & $\begin{array}{l}\text { Rajanpur } \\
\text { district }\end{array}$ & $\begin{array}{l}\text { All districts } \\
\text { maximum } \\
\text { value }\end{array}$ & $\begin{array}{l}\text { All districts } \\
\text { minimum } \\
\text { value }\end{array}$ \\
\hline \multicolumn{8}{|c|}{ Adaptive capacity } \\
\hline \multirow{7}{*}{$\begin{array}{l}\text { Livelihood } \\
\text { strategy }\end{array}$} & Dependency on agriculture as major income source & $\%$ & 94 & 78 & 93 & 100 & 0 \\
\hline & $\begin{array}{l}\text { Non-farm activates of households affected by natural } \\
\text { disasters as floods }\end{array}$ & $\%$ & 77 & 69 & 75 & 100 & 0 \\
\hline & $\begin{array}{l}\text { Household percentage those member or head having } \\
\text { opportunity of training to cope of other or flood } \\
\text { disasters }\end{array}$ & $\%$ & 8 & 13 & 9 & 100 & 0 \\
\hline & $\begin{array}{l}\text { Agricultural livelihood average diversification index } \\
\text { as range }(0.20-1)\end{array}$ & $\begin{array}{l}\text { 1/liveliho } \\
\text { od }\end{array}$ & 0.37 & 0.37 & 0.37 & 1 & 0.20 \\
\hline & $\begin{array}{l}\text { Household percentage as their member working in } \\
\text { various communities }\end{array}$ & $\%$ & 32 & 28 & 31 & 100 & 0 \\
\hline & $\begin{array}{l}\text { Household percentage have job opportunities in flood } \\
\text { season }\end{array}$ & $\%$ & 27 & 43 & 28 & 100 & 0 \\
\hline & Household percentage those fishing in flood season & $\%$ & 39 & 37 & 38 & 100 & 0 \\
\hline \multirow{5}{*}{$\begin{array}{l}\text { Social } \\
\text { demographic } \\
\text { factors }\end{array}$} & Dependency ratio & Ratio & 0.59 & 0.34 & 0.58 & 3 & 0 \\
\hline & Household average family number members & Count & 7.8 & 6.3 & 7.2 & 26 & 0 \\
\hline & Female headed percentage & $\%$ & 9 & 5 & 7 & 100 & 0 \\
\hline & $\begin{array}{l}\text { Household head percentage those not attended } \\
\text { schooling }\end{array}$ & $\%$ & 89 & 78 & 86 & 100 & 0 \\
\hline & Literacy rate of households & $\%$ & 29.6 & 34.1 & 30.04 & 100 & 0 \\
\hline \multirow[t]{5}{*}{$\begin{array}{l}\text { Social } \\
\text { networks }\end{array}$} & $\begin{array}{l}\text { Borrowing average, lending money ratio range of } \\
(0.5-2)\end{array}$ & Ratio & $1 . .43$ & 1.51 & 1.45 & 2 & 0.50 \\
\hline & $\begin{array}{l}\text { Households percentage those focus govt institutions } \\
\text { for assistance in last twelve months }\end{array}$ & $\%$ & 67 & 59 & 63 & 100 & 0 \\
\hline & $\begin{array}{l}\text { Household percentage concerned organizations of } \\
\text { farmers }\end{array}$ & $\%$ & 27 & 36 & 28 & 100 & 0 \\
\hline & $\begin{array}{l}\text { Household percentage concerned in political } \\
\text { organization scenario }\end{array}$ & $\%$ & 34 & 47 & 35 & 100 & 0 \\
\hline & $\begin{array}{l}\text { Household percentage concerned to social } \\
\text { organization scenario }\end{array}$ & $\%$ & 13 & 25 & 14 & 100 & 0 \\
\hline \multicolumn{8}{|l|}{ Sensitivity } \\
\hline \multirow[t]{2}{*}{ Food } & $\begin{array}{l}\text { Insufficient food with number of average month in } \\
\text { range }(0-12)\end{array}$ & Months & 3.4 & 2.3 & 3.1 & 12 & 0 \\
\hline & $\begin{array}{l}\text { Household percentage acquire food primarily from } \\
\text { own farm }\end{array}$ & $\%$ & 91 & 83 & 89 & 100 & 0 \\
\hline
\end{tabular}




\begin{tabular}{|c|c|c|c|c|c|c|c|}
\hline & Index of diversifying average crop range (0-1) & 1/crops & 0.48 & 0.48 & 0.48 & 1 & 0 \\
\hline & In last three month worried about insufficient food & $\%$ & 89 & 78 & 83 & 100 & 0 \\
\hline & Household percentage not saving seed & $\%$ & 28 & 19 & 27 & 100 & 0 \\
\hline & $\begin{array}{l}\text { Household percentage that not custom of house stead } \\
\text { gardening }\end{array}$ & $\%$ & 25 & 16 & 21 & 100 & 0 \\
\hline \multirow[t]{6}{*}{ Health } & $\begin{array}{l}\text { Household percentage access of treatment to MBBS } \\
\text { doctor }\end{array}$ & $\%$ & 57 & 49 & 44 & 100 & 0 \\
\hline & Health facility access in average (minute) & Minutes & 178.91 & 154.01 & 169.87 & 450 & 0 \\
\hline & $\begin{array}{l}\text { Household percentage those family members having } \\
\text { chronic illness }\end{array}$ & $\%$ & 21 & 12 & 19 & 100 & 0 \\
\hline & $\begin{array}{l}\text { Household percentage during illness access of local } \\
\text { doctor treatment }\end{array}$ & $\%$ & 96 & 81 & 93 & 100 & 0 \\
\hline & Household percentage sanitary latrine access & $\%$ & 43 & 31 & 39 & 100 & 0 \\
\hline & $\begin{array}{l}\text { Household percentage with family members those } \\
\text { missed their work in last two weeks due to illness }\end{array}$ & $\%$ & 19 & 12 & 16 & 100 & 0 \\
\hline \multirow{3}{*}{$\begin{array}{l}\text { Production } \\
\text { and housing } \\
\text { means }\end{array}$} & Households percentage without solid structure houses & $\%$ & 92 & 76 & 89 & 100 & 0 \\
\hline & Household percentage affected by floods & $\%$ & 95 & 87 & 94 & 100 & 0 \\
\hline & Household percentage without production means & $\%$ & 41 & 32 & 38 & 100 & 0 \\
\hline \multirow[t]{4}{*}{ Water } & $\begin{array}{l}\text { Household percentage indicating community based } \\
\text { water conflicts }\end{array}$ & $\%$ & 27 & 19 & 24 & 100 & 0 \\
\hline & $\begin{array}{l}\text { Household percentage using unsafe or natural water } \\
\text { source }\end{array}$ & $\%$ & 31 & 23 & 28 & 100 & 0 \\
\hline & $\begin{array}{l}\text { Average time in minutes to access safe useable water } \\
\text { from sources }\end{array}$ & Minutes & 5.7 & 3.8 & 4.9 & 18 & 0 \\
\hline & $\begin{array}{l}\text { Household percentage access easily water from } \\
\text { tubewell }\end{array}$ & $\%$ & 68 & 66 & 67 & 100 & 0 \\
\hline \multicolumn{8}{|l|}{ Exposure } \\
\hline \multirow[t]{7}{*}{$\begin{array}{l}\text { Climate } \\
\text { variability }\end{array}$} & $\begin{array}{l}\text { In last } 10 \text { years, gradually facing increasing summer } \\
\text { duration }\end{array}$ & $\%$ & 89 & 84 & 86 & 100 & 0 \\
\hline & $\begin{array}{l}\text { In last } 10 \text { years, gradually facing increasing winter } \\
\text { duration }\end{array}$ & $\%$ & 5 & 6 & 7 & 100 & 0 \\
\hline & $\begin{array}{l}\text { In last } 10 \text { years, gradually facing increasing winter } \\
\text { season rainfall }\end{array}$ & $\%$ & 43 & 38 & 37 & 100 & 0 \\
\hline & $\begin{array}{l}\text { In last } 10 \text { years, gradually facing increasing monsoon } \\
\text { rainfall }\end{array}$ & $\%$ & 71 & 68 & 69 & 100 & 0 \\
\hline & In last 10 years, gradually facing increasing rainfall & $\%$ & 83 & 76 & 77 & 100 & 0 \\
\hline & $\begin{array}{l}\text { In last } 10 \text { years, gradually facing increasing } \\
\text { occurrence of hailstorm }\end{array}$ & $\%$ & 47 & 43 & 40 & 100 & 0 \\
\hline & In last 10 years, gradually facing increasing & $\%$ & 68 & 65 & 66 & 100 & 0 \\
\hline
\end{tabular}




\begin{tabular}{|c|c|c|c|c|c|c|c|}
\hline & occurrence of riverbank erosion & & & & & & \\
\hline & $\begin{array}{l}\text { In last } 10 \text { years, gradually facing increasing } \\
\text { temperature }\end{array}$ & $\%$ & 88 & 81 & 83 & 100 & 0 \\
\hline & $\begin{array}{l}\text { In last } 10 \text { years, gradually facing increasing } \\
\text { floodwater }\end{array}$ & $\%$ & 78 & 75 & 77 & 100 & 0 \\
\hline \multirow{6}{*}{$\begin{array}{l}\text { Natural } \\
\text { disasters }\end{array}$} & In last 10 years, flood events average number & Count & 4.9 & 4.7 & 4.6 & 6 & 0 \\
\hline & In last 10 years, drought events average number & Count & 1.2 & 1 & 1.1 & 2 & 0 \\
\hline & $\begin{array}{l}\text { In last } 10 \text { years, household respondents percentage } \\
\text { death and injured due to flood hazards }\end{array}$ & $\%$ & 13 & 8 & 11 & 100 & 0 \\
\hline & $\begin{array}{l}\text { In last } 10 \text { years average numbers embankment was } \\
\text { breached }\end{array}$ & Count & 3.2 & 2.1 & 2.7 & 5 & 0 \\
\hline & $\begin{array}{l}\text { Household percentage that not received warning of } \\
\text { natural disasters (embankment breach, hailstorms, } \\
\text { flash floods) }\end{array}$ & $\%$ & 37 & 19 & 29 & 100 & 0 \\
\hline & The month average number waterlogged land & Months & 5.4 & 4.1 & 4.9 & 12 & 0 \\
\hline
\end{tabular}


662 Table 3 Normalized sub-components and major components Livelihood Vulnerability indices (LVI)

\begin{tabular}{|c|c|c|c|c|c|c|c|}
\hline $\begin{array}{l}\text { Major } \\
\text { components }\end{array}$ & $\begin{array}{l}\text { Muzaffargar } \\
\text { h district }\end{array}$ & $\begin{array}{l}\text { Rahim } \\
\text { Yar Khan } \\
\text { district }\end{array}$ & $\begin{array}{l}\text { Rajanpur } \\
\text { district }\end{array}$ & Sub-components & $\begin{array}{l}\text { Muzaffa } \\
\text { rgarh } \\
\text { district }\end{array}$ & $\begin{array}{l}\text { Rahim } \\
\text { Yar Khan } \\
\text { district }\end{array}$ & $\begin{array}{l}\text { Rajanpur } \\
\text { district }\end{array}$ \\
\hline \multicolumn{8}{|l|}{$\begin{array}{l}\text { Adaptive } \\
\text { capacity }\end{array}$} \\
\hline \multirow{7}{*}{$\begin{array}{l}\text { Livelihood } \\
\text { strategy }\end{array}$} & 0.403 & 0.419 & 0.427 & Dependency on agriculture as major income source & 0.940 & 0.780 & 0.930 \\
\hline & & & & $\begin{array}{l}\text { Non-farm activates of households affected by natural disasters } \\
\text { as floods }\end{array}$ & 0.770 & 0.690 & 0.750 \\
\hline & & & & $\begin{array}{l}\text { Household percentage those member or head having } \\
\text { opportunity of training to cope of other or flood disasters }\end{array}$ & 0.080 & 0.130 & 0.090 \\
\hline & & & & $\begin{array}{l}\text { Agricultural livelihood average diversification index as range } \\
(0.20-1)\end{array}$ & 0.254 & 0.254 & 0.252 \\
\hline & & & & $\begin{array}{l}\text { Household percentage as their member working in various } \\
\text { communities }\end{array}$ & 0.320 & 0.280 & 0.310 \\
\hline & & & & Household percentage have job opportunities in flood season & 0.270 & 0.430 & 0.280 \\
\hline & & & & Household percentage those fishing in flood season & 0.190 & 0.370 & 0.380 \\
\hline \multirow{5}{*}{$\begin{array}{l}\text { Social } \\
\text { demographic } \\
\text { factors }\end{array}$} & 0.158 & 0.176 & 0.174 & Dependency ratio & 0.196 & 0.113 & 0.193 \\
\hline & & & & Household average family number members & 0.198 & 0.154 & 0.167 \\
\hline & & & & Female headed percentage & 0.090 & 0.050 & 0.070 \\
\hline & & & & Household head percentage those not attended schooling & 0.110 & 0.220 & 0.140 \\
\hline & & & & Literacy rate of households & 0.196 & 0.341 & 0.300 \\
\hline \multirow[t]{5}{*}{ Social networks } & 0.424 & 0.491 & 0.429 & Borrowing average, lending money ratio range of (0.5-2) & 0.712 & 0.789 & 0.745 \\
\hline & & & & $\begin{array}{l}\text { Households percentage those focus govt institutions for } \\
\text { assistance in last twelve months }\end{array}$ & 0.670 & 0.590 & 0.630 \\
\hline & & & & Household percentage concerned organizations of farmers & 0.270 & 0.360 & 0.280 \\
\hline & & & & $\begin{array}{l}\text { Household percentage concerned in political organization } \\
\text { scenario }\end{array}$ & 0.340 & 0.470 & 0.350 \\
\hline & & & & $\begin{array}{l}\text { Household percentage concerned to social organization } \\
\text { scenario }\end{array}$ & 0.130 & 0.250 & 0.140 \\
\hline \multicolumn{8}{|c|}{ ( } \\
\hline \multirow[t]{5}{*}{ Food } & 0.515 & 0.438 & 0.490 & $\begin{array}{l}\text { Insufficient food with number of average month in range (0- } \\
\text { 12) }\end{array}$ & 0.283 & 0.191 & 0.258 \\
\hline & & & & Household percentage acquire food primarily from own farm & 0.910 & 0.830 & 0.890 \\
\hline & & & & Index of diversifying average crop range $(0-1)$ & 0.480 & 0.480 & 0.480 \\
\hline & & & & In last three month worried about insufficient food & 0.890 & 0.780 & 0.830 \\
\hline & & & & Household percentage not saving seed & 0.280 & 0.190 & 0.270 \\
\hline
\end{tabular}




\begin{tabular}{|c|c|c|c|c|c|c|c|}
\hline & & & & $\begin{array}{l}\text { Household percentage that not custom of house stead } \\
\text { gardening }\end{array}$ & 0.250 & 0.160 & 0.210 \\
\hline \multirow[t]{6}{*}{ Health } & 0.460 & 0.365 & 0.414 & Household percentage access of treatment to MBBS doctor & 0.570 & 0.490 & 0.440 \\
\hline & & & & Health facility access in average (minute) & 0.398 & 0.342 & 0.377 \\
\hline & & & & $\begin{array}{l}\text { Household percentage those family members having chronic } \\
\text { illness }\end{array}$ & 0.210 & 0.120 & 0.190 \\
\hline & & & & $\begin{array}{l}\text { Household percentage during illness access of local doctor } \\
\text { treatment }\end{array}$ & 0.960 & 0.810 & 0.930 \\
\hline & & & & Household percentage sanitary latrine access & 0.430 & 0.310 & 0.390 \\
\hline & & & & $\begin{array}{l}\text { Household percentage with family members those missed } \\
\text { their work in last two weeks due to illness }\end{array}$ & 0.190 & 0.120 & 0.160 \\
\hline \multirow{3}{*}{$\begin{array}{l}\text { Production and } \\
\text { housing means }\end{array}$} & 0.760 & 0.650 & 0.737 & Households percentage without solid structure houses & 0.920 & 0.760 & 0.890 \\
\hline & & & & Household percentage affected by floods & 0.950 & 0.870 & 0.940 \\
\hline & & & & Household percentage without production means & 0.410 & 0.320 & 0.380 \\
\hline \multirow[t]{4}{*}{ Water } & 0.360 & 0.303 & 0.337 & $\begin{array}{l}\text { Household percentage indicating community based water } \\
\text { conflicts }\end{array}$ & 0.270 & 0.190 & 0.240 \\
\hline & & & & Household percentage using unsafe or natural water source & 0.310 & 0.230 & 0.280 \\
\hline & & & & $\begin{array}{l}\text { Average time in minutes to access safe useable water from } \\
\text { sources }\end{array}$ & 0.181 & 0.134 & 0.157 \\
\hline & & & & Household percentage access easily water from tubewell & 0.680 & 0.660 & 0.670 \\
\hline \multicolumn{8}{|l|}{ Exposure } \\
\hline \multirow{9}{*}{$\begin{array}{l}\text { Climate } \\
\text { variability }\end{array}$} & 0.635 & 0.595 & 0.602 & In last 10 years, gradually facing increasing summer duration & 0.890 & 0.840 & 0.860 \\
\hline & & & & In last 10 years, gradually facing increasing winter duration & 0.050 & 0.060 & 0.070 \\
\hline & & & & $\begin{array}{l}\text { In last } 10 \text { years, gradually facing increasing winter season } \\
\text { rainfall }\end{array}$ & 0.430 & 0.380 & 0.370 \\
\hline & & & & In last 10 years, gradually facing increasing monsoon rainfall & 0.710 & 0.680 & 0.690 \\
\hline & & & & In last 10 years, gradually facing increasing rainfall & 0.830 & 0.760 & 0.770 \\
\hline & & & & $\begin{array}{l}\text { In last } 10 \text { years, gradually facing increasing occurrence of } \\
\text { hailstorm }\end{array}$ & 0.470 & 0.430 & 0.400 \\
\hline & & & & $\begin{array}{l}\text { In last } 10 \text { years, gradually facing increasing occurrence of } \\
\text { riverbank erosion }\end{array}$ & 0.680 & 0.650 & 0.660 \\
\hline & & & & In last 10 years, gradually facing increasing temperature & 0.880 & 0.810 & 0.830 \\
\hline & & & & In last 10 years, gradually facing increasing floodwater & 0.780 & 0.750 & 0.770 \\
\hline \multirow[t]{3}{*}{ Natural disasters } & 0.501 & 0.386 & 0.444 & In last 10 years, flood events average number & 0.816 & 0.783 & 0.766 \\
\hline & & & & In last 10 years, drought events average number & 0.600 & 0.500 & 0.550 \\
\hline & & & & $\begin{array}{l}\text { In last } 10 \text { years, household respondents percentage death and } \\
\text { injured due to flood hazards }\end{array}$ & 0.130 & 0.080 & 0.110 \\
\hline
\end{tabular}




\begin{tabular}{|l|l|l|l|l|l|l|}
\hline & & & In last 10 years average numbers embankment was breached & 0.640 & 0.420 & 0.540 \\
\cline { 2 - 7 } & & & $\begin{array}{l}\text { Household percentage that not received warning of natural } \\
\text { disasters (embankment breach, hailstorms, flash floods) }\end{array}$ & 0.370 & 0.190 & 0.290 \\
& & The month average number waterlogged land & 0.450 & 0.341 & 0.408 \\
\cline { 2 - 8 } & & & 0.471 & 0.430 & 0.452 \\
\hline
\end{tabular}


690 Table 4 Livelihood vulnerability index with contributing IPCC factors

\begin{tabular}{|c|c|c|c|c|c|c|c|}
\hline \multirow{2}{*}{$\begin{array}{l}\text { Contributing } \\
\text { factors of IPCC }\end{array}$} & \multicolumn{3}{|c|}{ Values of contributing factors IPCC } & \multirow{2}{*}{$\begin{array}{l}\text { Major } \\
\text { components }\end{array}$} & \multicolumn{3}{|c|}{ Values of major components } \\
\hline & $\begin{array}{l}\text { Muzaffargarh } \\
\text { district }\end{array}$ & $\begin{array}{l}\text { Rahim Yar Khan } \\
\text { district }\end{array}$ & Rajanpur district & & $\begin{array}{l}\text { Muzaffargarh } \\
\text { district }\end{array}$ & $\begin{array}{l}\text { Rahim Yar Khan } \\
\text { district }\end{array}$ & Rajanpur district \\
\hline \multirow[t]{3}{*}{$\begin{array}{l}\text { Adaptive } \\
\text { capacity }\end{array}$} & 0.328 & 0.362 & 0.343 & $\begin{array}{l}\text { Livelihood } \\
\text { strategy }\end{array}$ & 0.403 & 0.419 & 0.427 \\
\hline & & & & $\begin{array}{l}\text { Social } \\
\text { demographic } \\
\text { factors }\end{array}$ & 0.158 & 0.176 & 0.174 \\
\hline & & & & Social networks & 0.424 & 0.491 & 0.429 \\
\hline \multirow[t]{4}{*}{ Sensitivity } & 0.524 & 0.439 & 0.495 & Food & 0.515 & 0.438 & 0.490 \\
\hline & & & & Health & 0.460 & 0.365 & 0.414 \\
\hline & & & & $\begin{array}{l}\text { Production and } \\
\text { housing means }\end{array}$ & 0.760 & 0.650 & 0.737 \\
\hline & & & & Water & 0.360 & 0.303 & 0.337 \\
\hline \multirow[t]{2}{*}{ Exposure } & 0.568 & 0.491 & 0.523 & $\begin{array}{l}\text { Climate } \\
\text { variability }\end{array}$ & 0.635 & 0.595 & 0.602 \\
\hline & & & & Natural disasters & 0.501 & 0.386 & 0.444 \\
\hline \multicolumn{4}{|c|}{ Livelihood vulnerability index of IPCC (LVI-IPCC) } & & 0.087 & 0.038 & 0.079 \\
\hline
\end{tabular}

691 


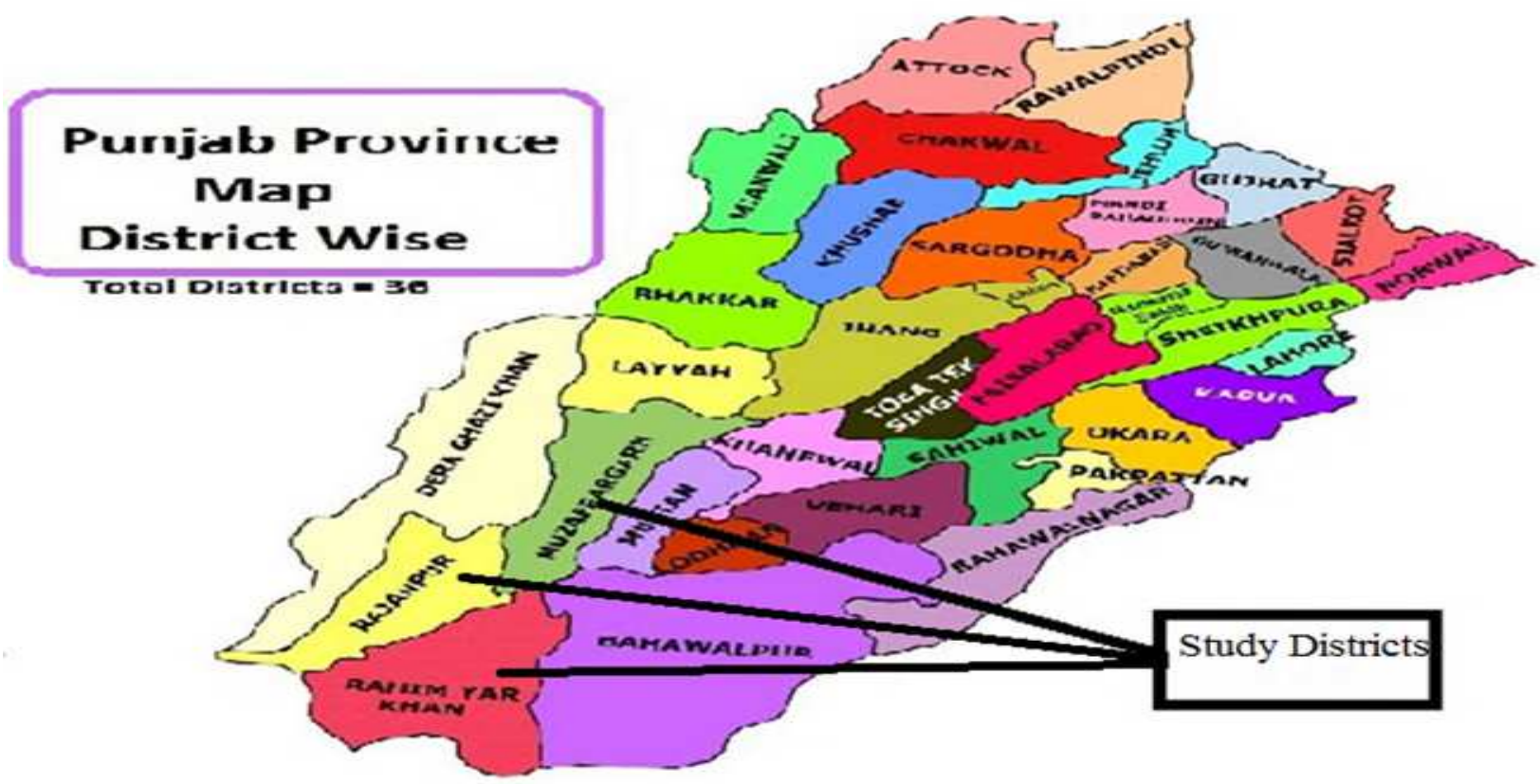




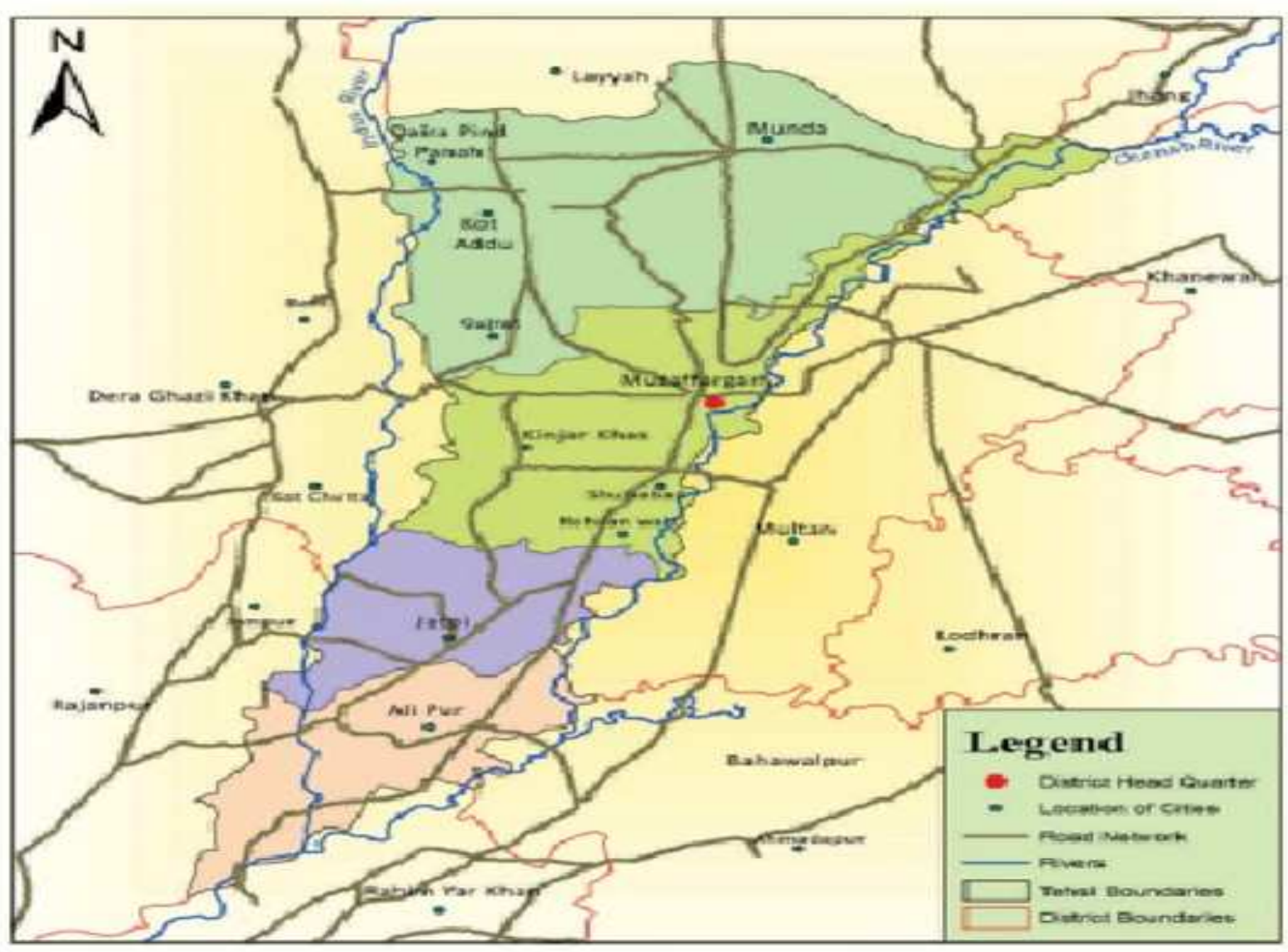


729 Figure 3 Three Bait households districts Livelihood Vulnerability Index (LVI) major components with spider diagram

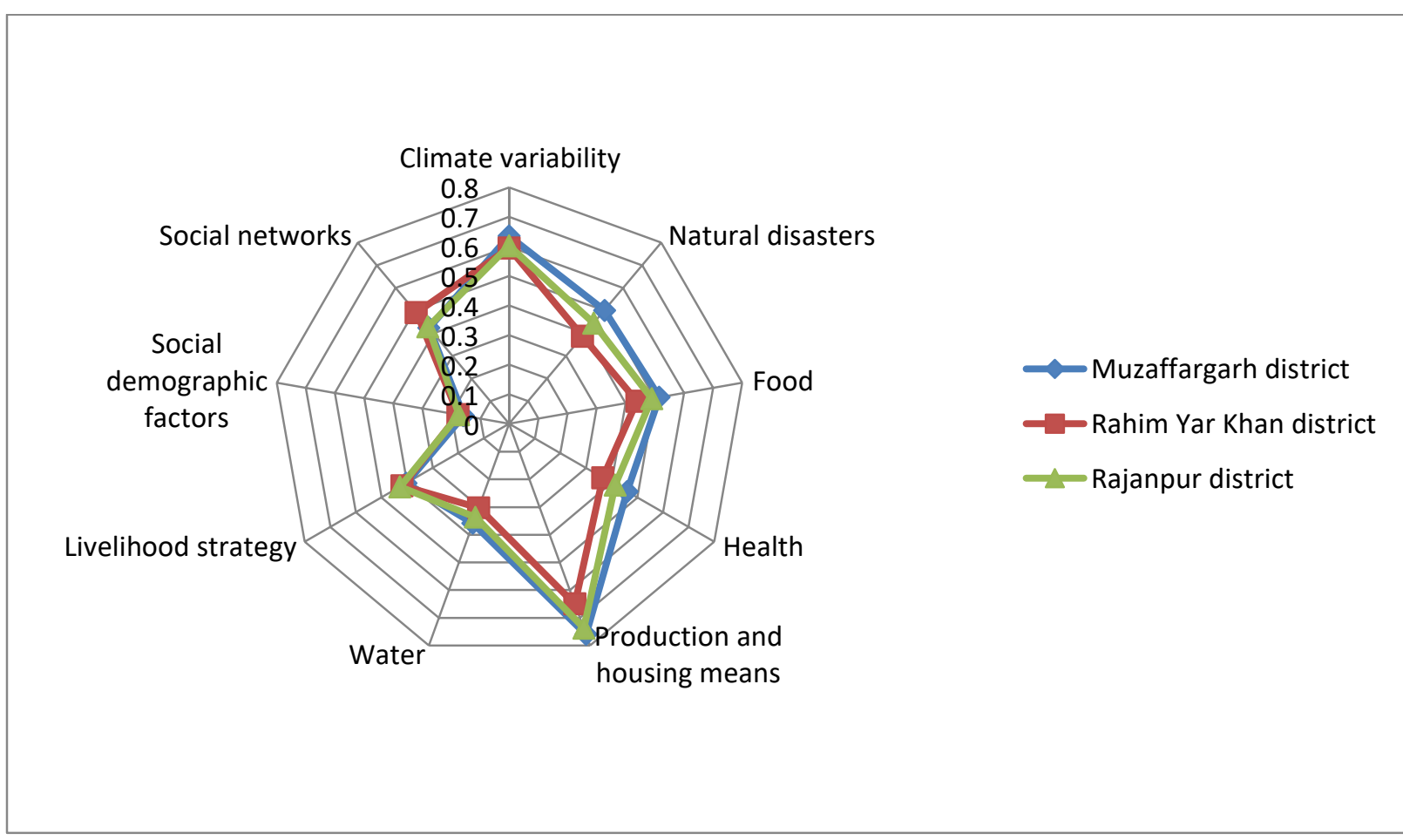


Figure 4 Three districts Bait community vulnerability LVI-IPCC scores in triangle diagram

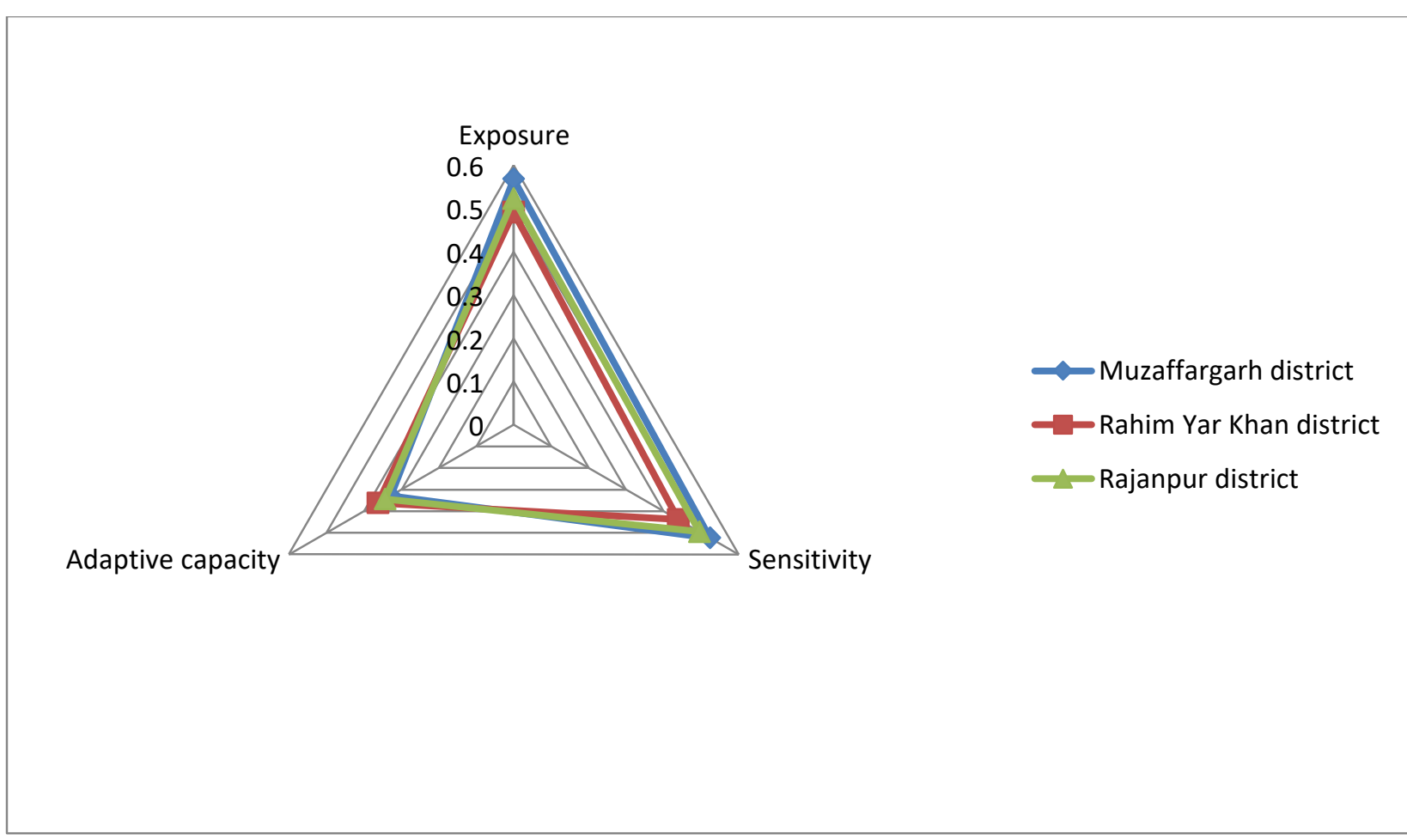

